
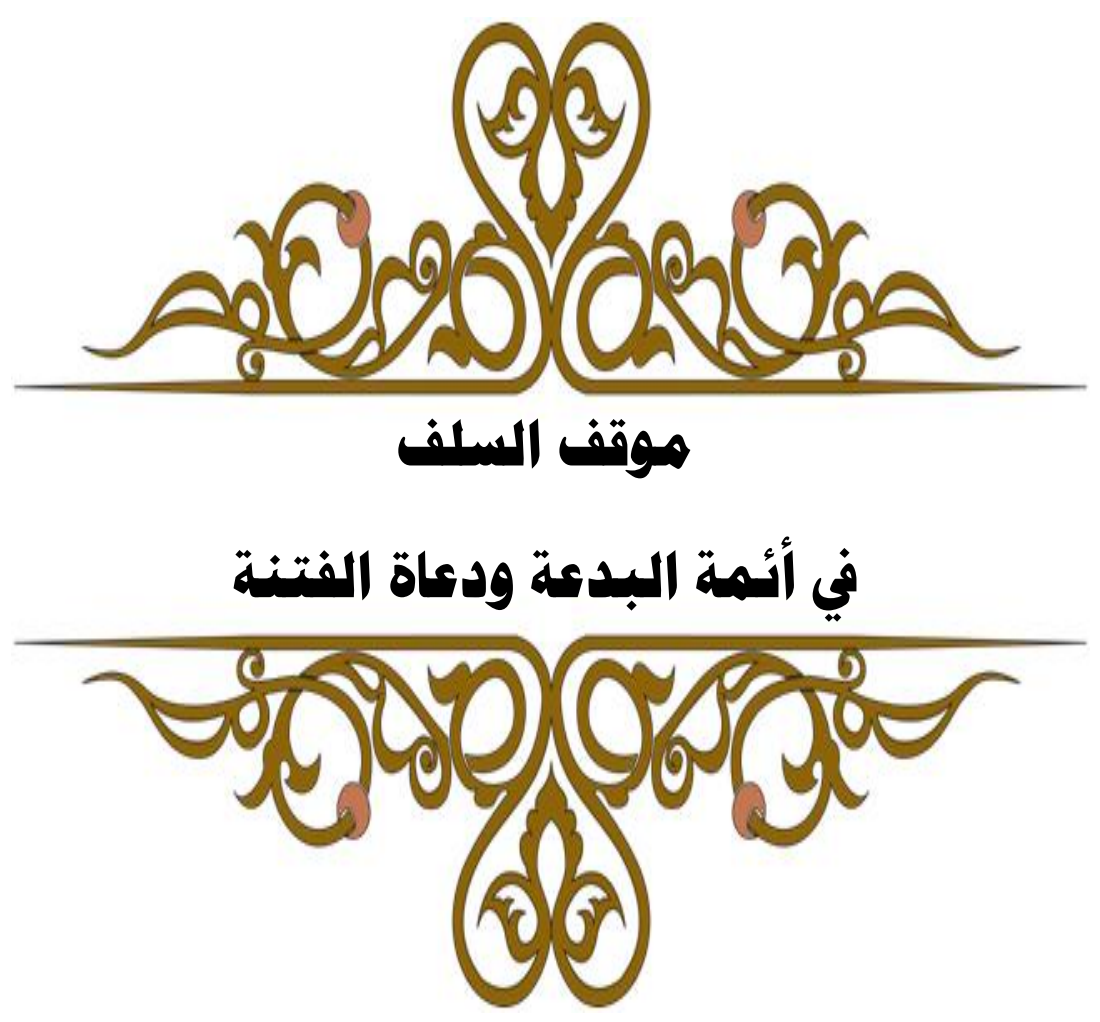

\title{
إعداد
}

الباحث الدكتهر

عبد المنعم عبد الغفور أسرار

الأستاذ المشارك في معهد تعليم اللغة

العربية للناطقين بغيرها بجامعة أم القرى مكة المكرمة

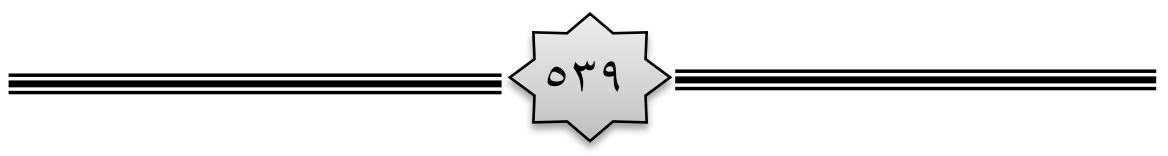




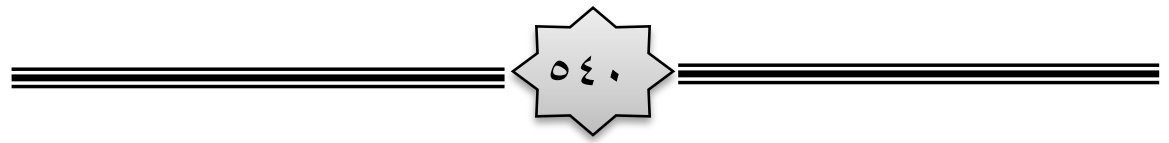




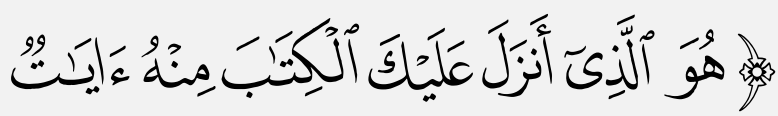

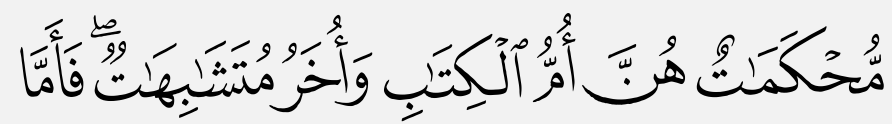

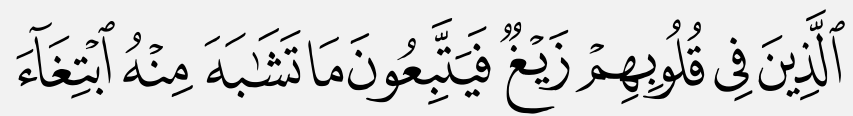

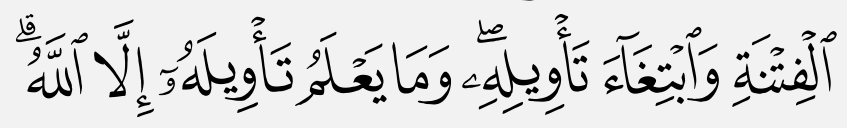

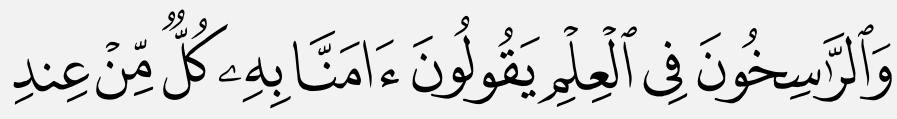

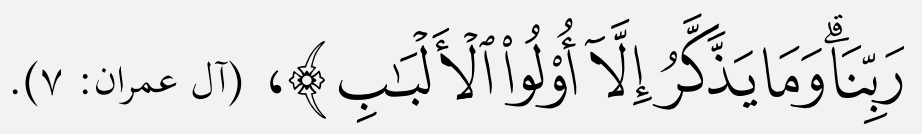

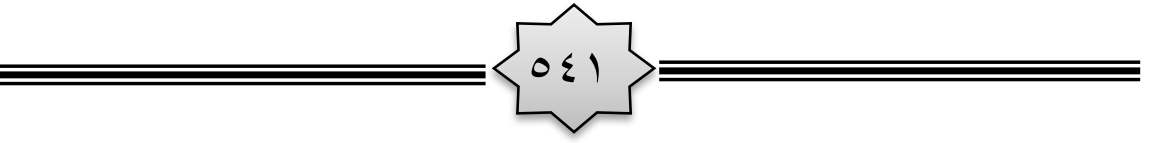




\section{ملفص البمث}

ملخص البحث بعنوان: (موقف السلف في أئمة البدعة ودعاة الفتنة).

تواترت نصوص الثرع الحكيم والآثار الواردة عن السلف الصالح في

تقرير أصل مهم وهو: الأمر بالاتباع والنهي عن الابتداع، وقد حرص الباحث

على إبراز بعض هذه النصوص والآثار كمثال على المراد؛ لأنها كثيرة

$$
\text { يصعب حصرها. }
$$

وقد أراد الباحث من بحثه هذا التتبيه على ثلاث حقائق مهمّة وهي: أن

ما ورد عن الأئمة من حمل بعض نصوص الكتاب والسنة على أهل البدع إنما هو تفسير للآية ببعض ما تدلّ عليه، وأما ما ورد عنهم في الإغلاظ على أهل البدع فإنما قالوه في سياق تاريخي، وأحوال للأمة تختلف كثيراً عما نحن

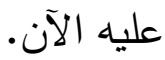

و الله الموفّق وعليه التكلان. 
Salaf's position regarding the leaders of innovation and perpetrators

of trauma

Dr.

\title{
Abd El-Mon'em Abd Al-Ghafur
}

\begin{abstract}
Subject: Salaf's position regarding the leaders of innovation and perpetrators of trauma.
\end{abstract}

Commonly proofs of the complete religion and the reported quotes from the pious predecessors in establishing the great fundamental of Deen which is the commandment to obey the religious rules and the abstaining from religious heresy, The researcher has decided to showcase parts of these proofs and quotes to explain the intended meaning because they are many and they are difficult to state in full.

The researcher has intended to clarify three essential facts with this research and they are: using some proofs of the Qur'an and the Sunnah against the innovators by the scholars was based on interpretation of the verses by parts of what the

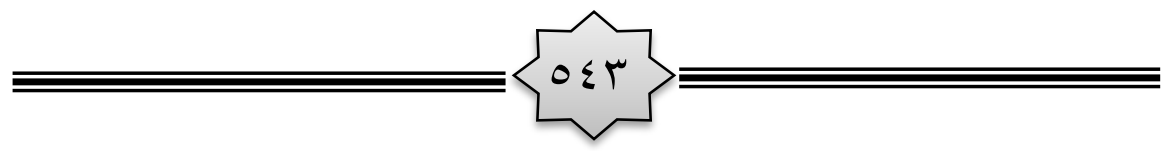


verses denote, also the scholars' harshness on the innovators was based on historical events, and some national issues that are totally different from what we are facing now.

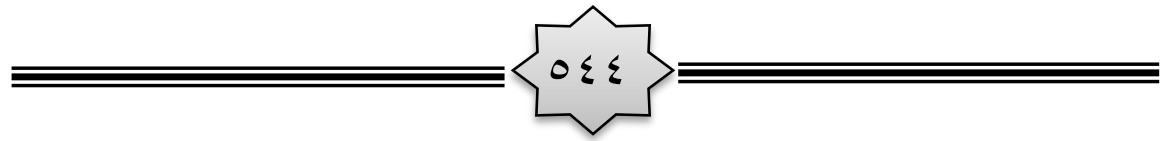




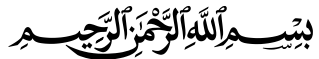

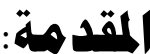

إنَّ الحمد لله نحمده ونستعينه ونستغفره، ونعوذ بالله من شرور أنفسنا، ومن سيئات أعمالنا، من يهده الله فلا مضل له، ومن يضلل فلا هادي له، وأشهد أن لا إله إلاًّ الله وحده لا شريك

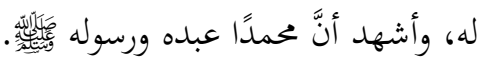
(1).



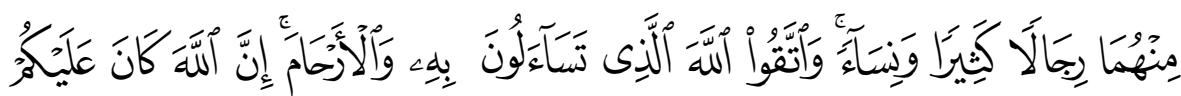

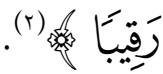

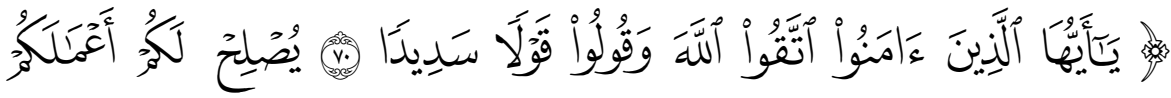

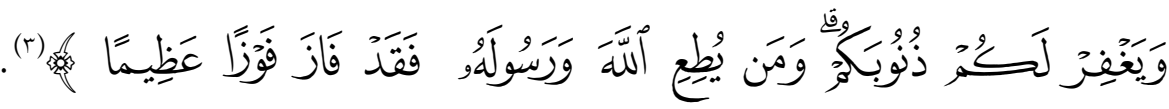

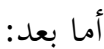

$$
\begin{aligned}
& \text { (') آل عمران: ب. I. } \\
& \text { (َ) النساء: } 1 .
\end{aligned}
$$

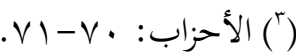

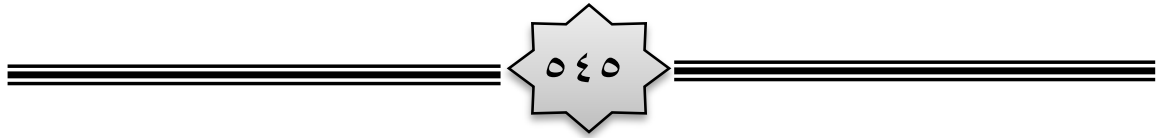


فإن الله تعالى قد تكفّل بحفظ هذا الدين بنفسه؛ لأنه أراد أن يكون هو

الدين الخاتم للناس إلى أن يرث الله الأرض ومن عليها قال تعالى:

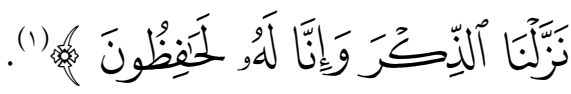

ولهذا فإن نصوص الثرع قد تضافرت في الأمر بهذا الأصل العظيم من

الأمر بالاتباع والنهي عن الابتداع والإحداث في دين الله ما ليس منه، كما أن الآثار الواردة عن القرون المفضّلة ومن بعدهم من الأئمة قد تواترت بالأمر بالاعتصام بشرع الله المنزّل ولزوم ما كان عليه النبي وأصحابه وسلف الأمة في القرون المفضّلة، والتحذير من البدع وأهلها، والأمر بمجانبتهم وهجرهم، ونحو ذلك من الأمور التي تحمي الدين من التغيير والتبديل الذي

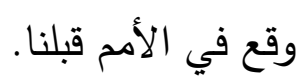

وإن المتأمّل في الحشد الهائل من الروايات الواردة عن أئمة السلف الصالح رحمهم الله تعالى في شأن الابتداع في الدين يجد أنهم قد اتخذوا موقفاً حازماً لا هوادة فيه في ذم البدع والتحذير منها ومن أهلها، وربما المبالغة في عقوبتهم وهجرهم. . $9:$ : (الحجر (') 
وهذا جعل كثيراً من المنتسبين للسنة في عصرنا الحاضر يتخذ نحو

هذا المواقف القاسية في حق كثير ممن فعل البدعة أو وقع في شيء منها، وربما تشنج بعضهم حتى وقع في الظلم المحرم والبغي المنهي عنه من غيبة وبهتان وهمز ولمز، وربما بلغ الأمر ببعضهم إلى الاعتداء والعدوان على مسلم في نفسه أو عرضه أو ماله أو أهله، وتعظم المصيبة أكثر أنه يلبس ما ارتكبه من بهتان وإثم عظيم يلبسه بلباس الحرص على العقيدة، والدفاع عن السنة، وأنه إنما بفعله يقوم بقربة وطاعة هي من أجل القرب والطاعات وهو إحقاق الحق وإزهاق الباطل، ونحو ذلك من الصفات التي يطلقها على نفسه أو على من يعظّمه من متبوع، وكثير من هؤلاء إنما هو منتصر لنفسه متبع لكثير من أهوائها وأشدها بلاء الكبر والحسد، ثم إنه إن وُعظ في ذلك وذُكّر باله عز وجل أجاب بترديد شيء من هذه الآثار لأئمة كبار زاعماً أنه إنما سائر على هديهم ونهجهم.

قال شيخ الإسلام: (وإذا كان الرجل يترك الصلوات ويرتكب المنكرات وقد عاشره من يخاف أن يفسد دينه: بين أمره له لتتقى معاشرته. وإذا كان مبتدعا يدعو إلى عقائد تخالف الكتاب والسنة أو يسلك طريقا يخالف الكتاب والسنة ويخاف أن يضل الرجل الناس بذلك: بين أمره للناس ليتقوا 
ضلاله ويعلموا حاله. وهذا كله يجب أن يكون على وجه النصح وابتغاء وجه الله تعالى لا لهوى الشخص مع الإنسان: مثل أن يكون بينهما عداوة دنيوية أو تحاسد أو تباغض أو تنازع على الرئاسة فيتكلم بمساوئه مظهرا للنصح وقصده في الباطن الغض من الشخص واستيفاؤه منه فهذا من عمل الثيطان و 》إنما الأعمال بالنيات وإنما لكل امرئ ما نوى《 بل يكون الناصح قصده أن الله يصلح ذلك الثخص وأن يكفي المسلمين ضرره في دينهم ودنياهم ويسلك في هذا المقصود أيسر الطرق التي تمكنه)('). وهذا الهوى والجهل أثر نزيفاً هائلاً من رصيد الدعوة الإسلامية في كل البلاد، ولكن الله غالب على أمره، وإليه يرجع الأمر كله. ومن ههنا عقدت العزم مستعيناً باله تعالى على الكتابة في هذا الموضوع لتوضيح مراد السلف من الإغلاظ على المبتدعة وواقع العصر الذي وردت

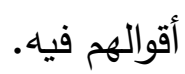

وقد حرصت أن تكون كتابتي في هذا الموضوع مستتيرة بنصوص الوحي وآثار السلف وما قاله الأئمة المحقّون، سالكاً المنهج التوصيفي في شرح مسائل البحث، وآخذاً بالمنهج التحليلي عند ذكر النصوص والاستدلال بها.

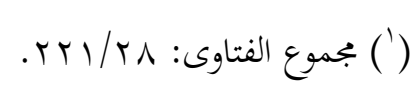


وكانت خطة البحث كالتالي:

$$
\text { أولاً: اشتمل البحث على: }
$$

مقدمة ذكرت فيها أهمية الموضوع ومنهج البحث وخطته.

$$
\text { وعلى خمسة مباحث هي: }
$$

المبحث الأول: الأدلة من القرآن الكريم في الأمر بالاتباع والنهي عن

المبحث الثاني: الأدلة من السنة النبوية في الأمر بالاتباع والنهي عن

المبحث الثالث: الآثار الواردة عن الصحابة رضي الله عنهم في الأمر

$$
\text { بالاتباع والنهي عن الابتداع. }
$$

المبحث الرابع: الآثار الواردة عن السلف الصالح رحمهم الله تعالى في

$$
\text { الأمر بالاتباع والنهي عن الابتداع. }
$$

المبحث الخامس: مراد السلف من التغليظ على أهل الأهواء والبدع.

ثانياً: ختمت البحث بخاتمة ذكرت فيها أهم النتائج المستخلصة من

$$
\text { البحث. }
$$


ثالثاً: قد اتبعت في عزو الآيات والأحاديث الواردة في البحث على

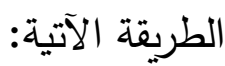

1 - عزوتُ الآيات إلى مواضعها في الكتاب العزيز بذكر اسم السورة ورقم الآية.

$$
\text { r - -عزوتُ الأحاديث إلى مصادرها كما يلي: }
$$

أ - إن كان الخبر في الصحيحين أو في أحدهما فإنني أكتفي بعزوه إلى

ب - إن لم يكن الخبر في الصحيحين أو في أحدهما فإنني أعزوه إلى مواضعه في بقية الكتب الستة وغيرها من كتب السنن والمعاجم والمسانيد. ج - وأعتمد في الحكم على الحديث إن لم يكن في الصحيحين أو أحدهما على أقوال الأئمة المحقِّين في هذا الثأن. رابعاً: ترجمت للأعلام غير المشهورين الذين وردت أسماؤهم في ثنايا البحث. خامساً: جعلت الهوامش متسلسلة في آخر البحث. 
سادساً: ذيّلت البحث بقائمة للمراجع والمصادر، وبقائمة أخرى لموضوعات

$$
\text { البحث ومحتوياته. }
$$

هذا وأسأل الله التوفيق والسداد إنه حسبنا ونعم الوكيل والحمدله رب

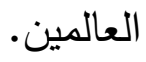

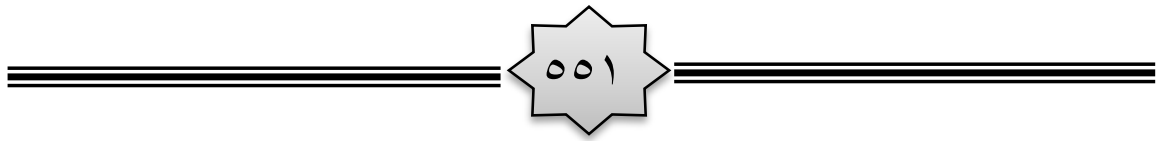


المبحث الأول: الأدلة من القرآن الكريم في الأمر بالاتباع والنهي عن الابتداع.

إن النصوص الواردة في تقرير هذا الأصل كثيرة يصعب حصر أفرادها

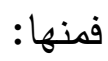

كل نص يأمر باتباع المحكم، وينهى عن اتباع المتثابه، ويأمر بسلوك

الصراط المستقيم وسبيل الله، وينهى من اتباع سبل الثيطان والضلال، ويأمر بالاعتصام بحبل الله والجماعة، وينهى عن الفرقة والاختلاف.

ومنها: كل نص يأمر بطاعة الله ورسوله، وتحكيمهما في كل

شيء، وينهى عن طاعة غير الله ورسوله، وتحكيم غير شرعه، واتباع الهوى، وما كان عليه الآباء والأجداد.

ومنها: كل نص فيه الوعيد الثديد على من كذب على الله

ورسوله، وافترى على الدين بغير علم.

ومنها: كل نص فيه الإنكار الثديد على بدع المشركين وأهل

الكتاب من تحليل ما حرّم الله، وتحريم ما أحلّ الله، وغير ذلك، ولتنكر بعضاً

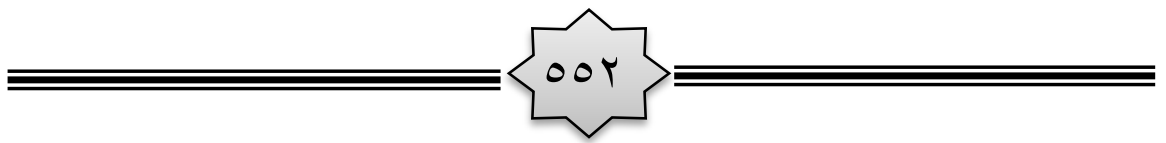


من هذه النصوص على سبيل الإثارة والتمثيل لبيان المراد، لا على سبيل الإحاطة والحصر.

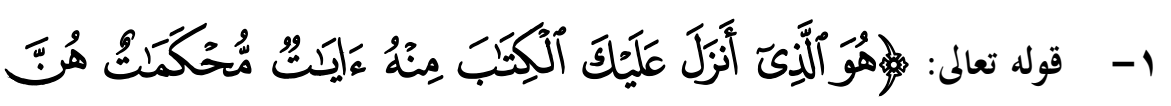

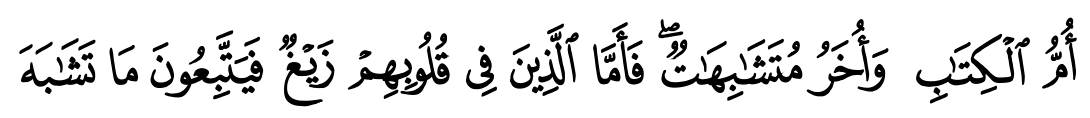

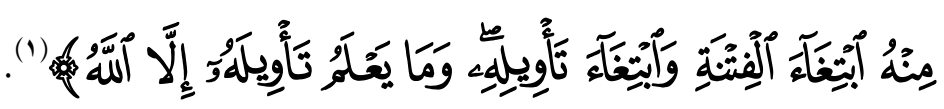

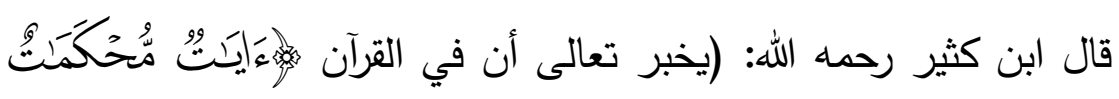

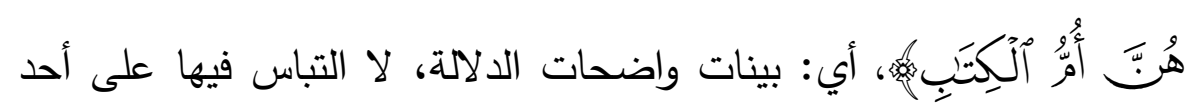

من الناس، ومنه آيات أخر فيها اشتباه في الدلالة على كثير من الناس أو بعضهم، فمن رد ما اشتبه عليه إلى الواضح منه، وحكم محكمه على متثابهه

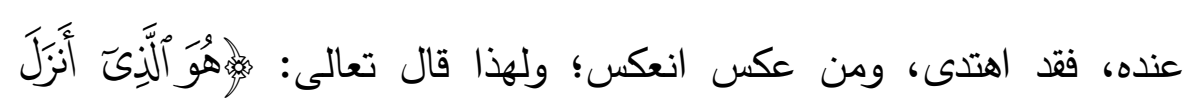

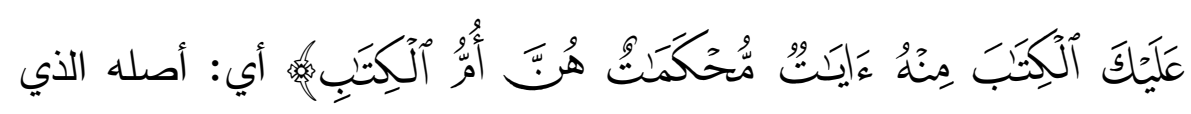

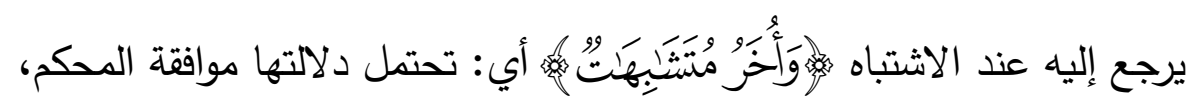
وقد تحتمل شيئا آخر من حيث اللفظ والتركيب، لا من حيث المراد)(r).

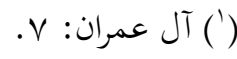

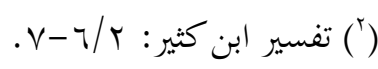


روت عائشة رضي الله عنها أن رسول الله بيلكة تلا هذه الآية ثم قال: لاوإذا رأيت الذين يتّبعون ما تشابه منه فأولئك الذين سمّى الله، فاحذروهمب( ').

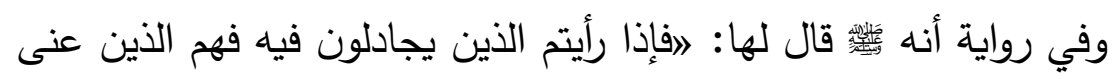

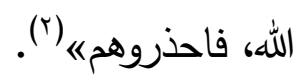

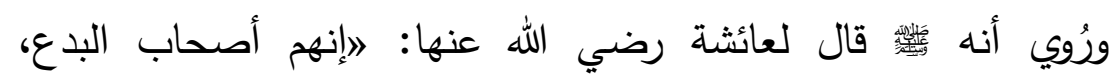
وأصحاب الأهواء، وأصحاب الضلالة من هذه الأمة، فاحذريهم يا عائشة، إن لكل صاحب ذنب توبة غير أصحاب البدع، ليس لهم توبة، أنا منهم بريء،

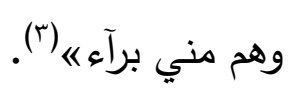

وفي هذا الموطن ذكر الأقوال الواردة في المحكم والمتشابه، كما أطال النفس في الكلام عن

$$
\begin{aligned}
& \text { حديث عائشة }
\end{aligned}
$$

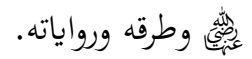

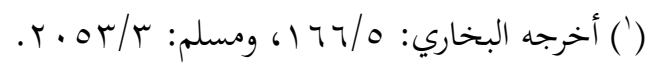

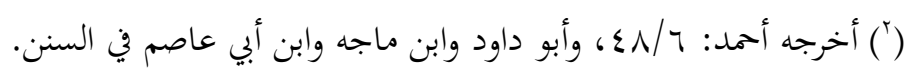

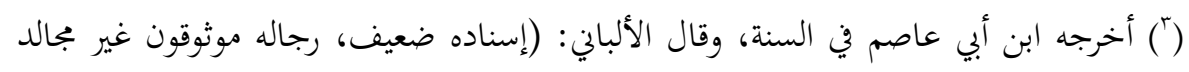

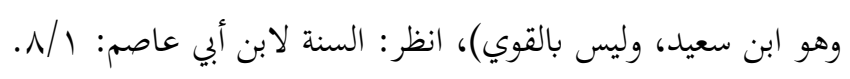

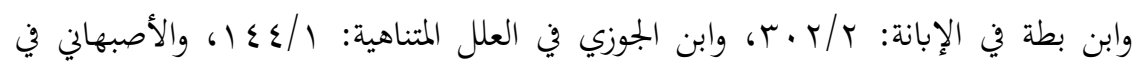

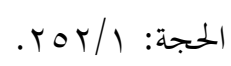

وقال الهيثمي: (رواه الطبراني في الصغير وفيه بقية وبجالد بن سعيد، وكلاهماضعيف)، مجمع

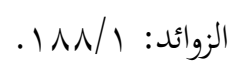




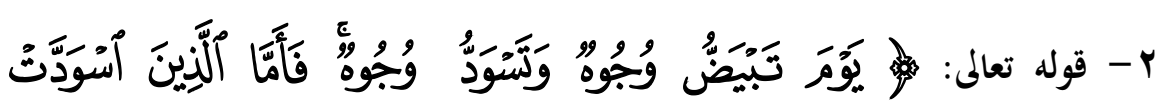

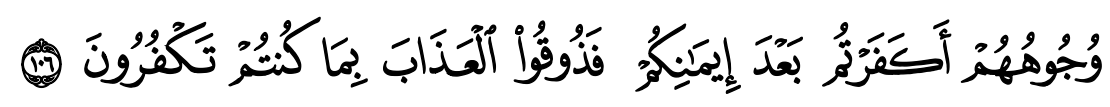

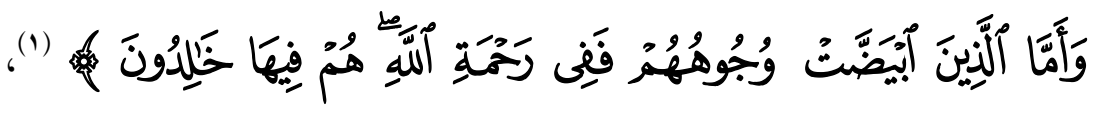

قال: (تبيض وجوه أهل السنة، وتسودّ وجوه أهل البدع)().

ونقل نحوه عن الحسن(") والإمام مالك (๕).

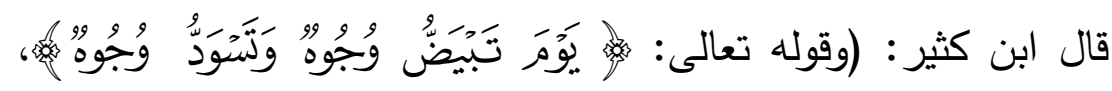

يعني: يوم القيامة، حين تبيضّ وجوه أهل السنة والجماعة، وتسودّ وجوه أهل البدعة والفرقة، قاله ابن عباس رضي الله عنهما)(•).

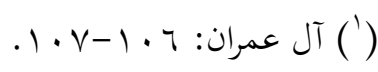

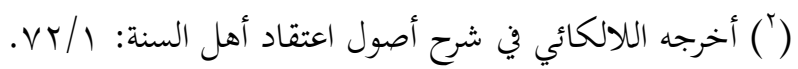

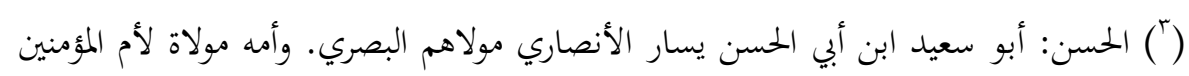

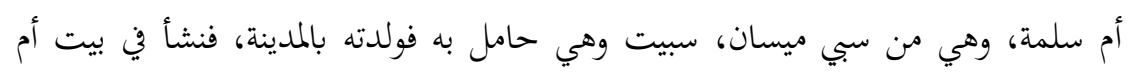

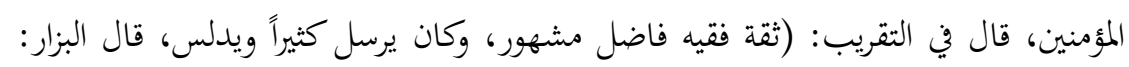

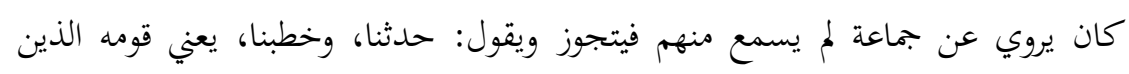

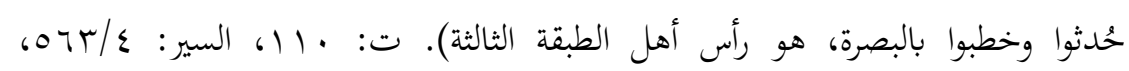

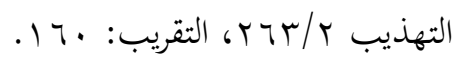

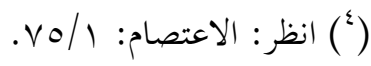

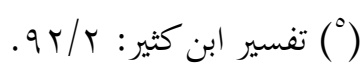




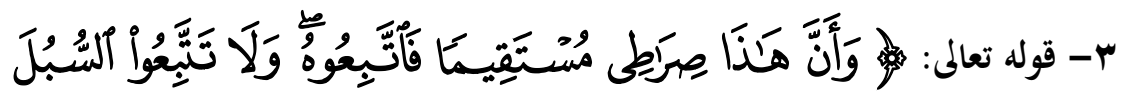

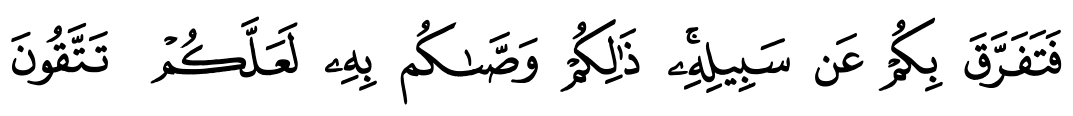

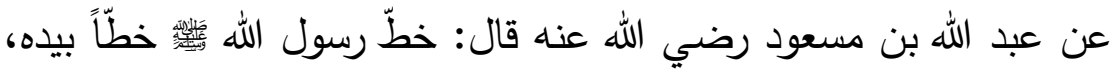
ثم قال: "هذا سبيل الله مستقيماً قال: ثم خطّ عن يمينه وشماله، ثم قال:

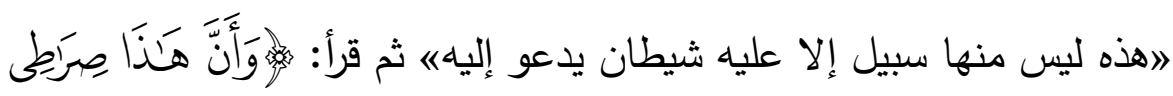

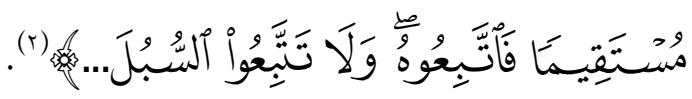

قال ابن مسعود رضي الله عنه: (عليكم بالطريق فلئن لزمتموه، لقد سبقتم سبقاً بعيداً، ولئن خالفتموه يمينا وشمالاً لقد ضللتم ضلالاً بعيداً) (؟). وعن حذيفة رضي الله عنه قال: (يا معشر القراء استقيموا فقد سبقتم سبقاً بعيداً، فإن أخذتم يمينا وشمالاً، لقد ضللتم ضلالاً بعيداً) (؛).

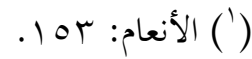

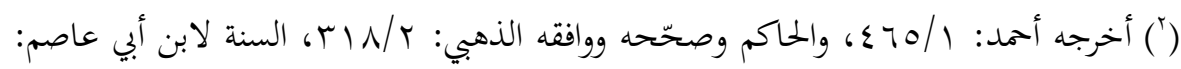

$$
\begin{aligned}
& \text { rا ا، وحسيّه الألباني. }
\end{aligned}
$$

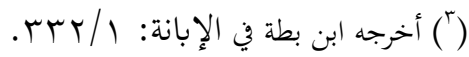

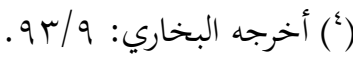


وعن مجاهد(')، أنه قال في الآية السابقة: (البدع والثبهات)(؟).

ومن الآيات الواردة في هذا الشأن:

ع- قوله تعالى:

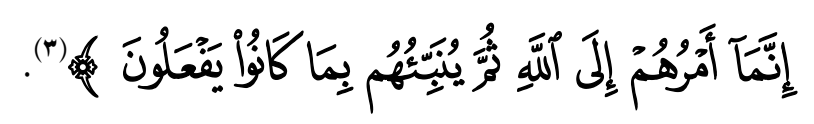

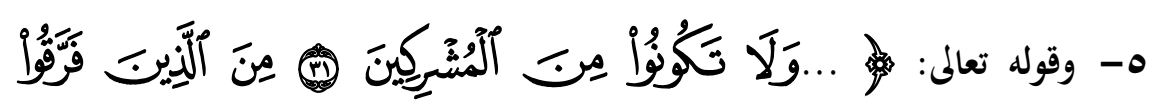

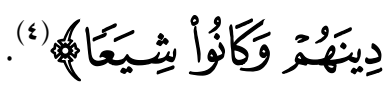

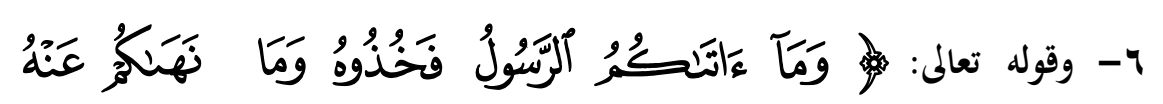

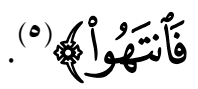

(') أبو الحجاج بجاهد بن جبر، إمام القراء والمفسّرين، المكي الأسود مولى السائب بن أبي ألمائ

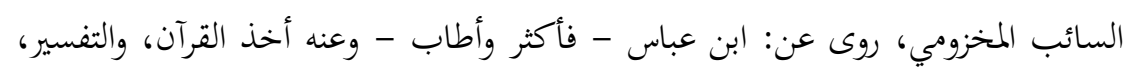

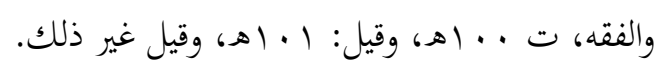

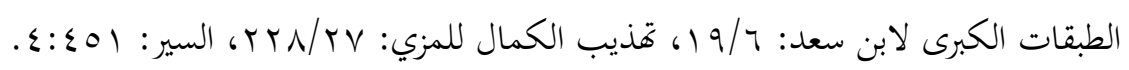

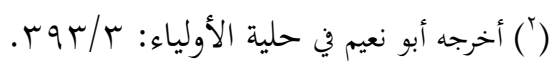

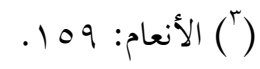

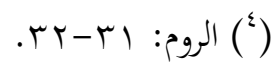

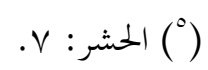

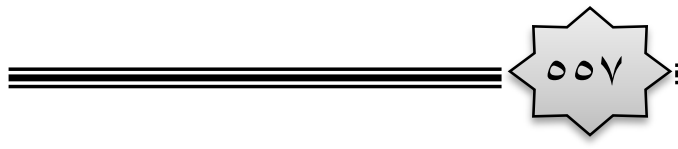




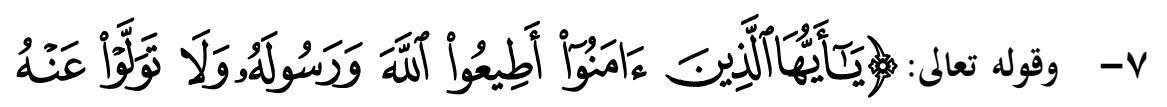

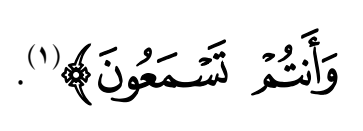

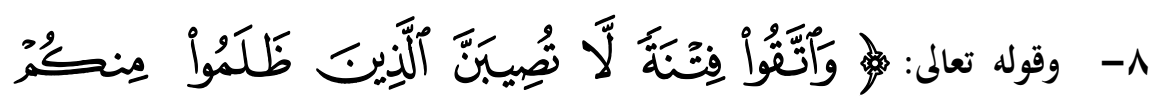

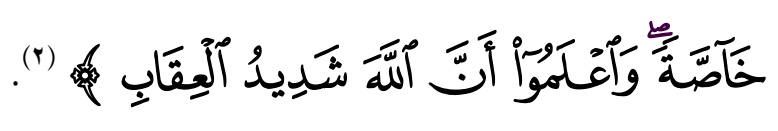

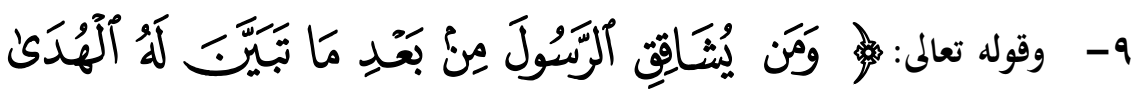

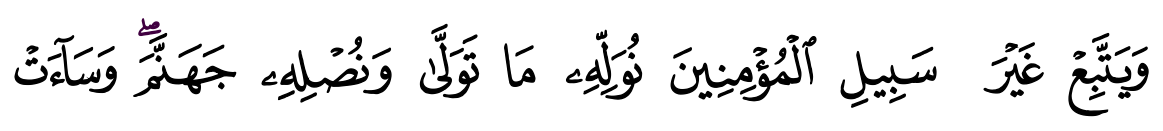
(5)

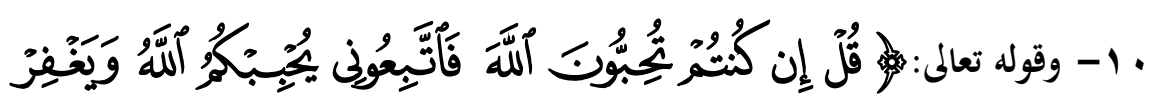

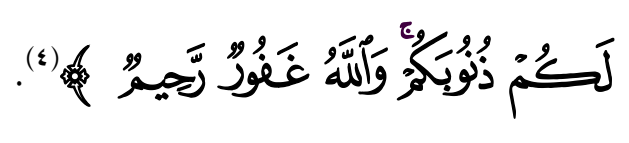

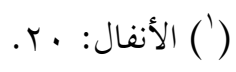

$$
\begin{aligned}
& \text { ro: الألنفال: (r) } \\
& \text { (") (") النساء: } 110 .
\end{aligned}
$$

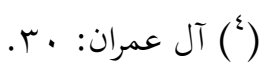




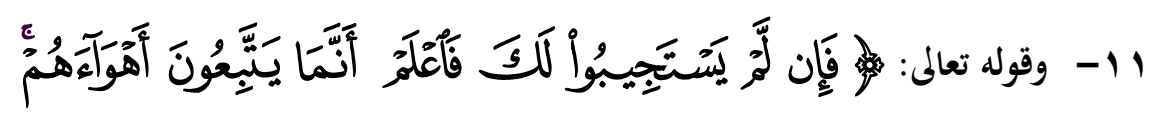

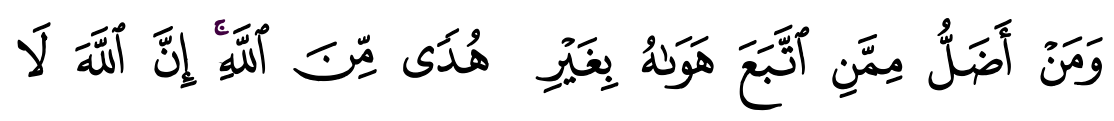

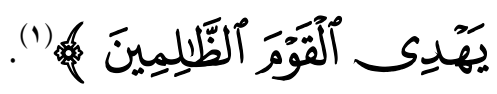

وقد ذكر الشاطبي كثيراً من هذه الآيات ، وأفاض في شرحها، ثم قال:

(والآيات المصرحة والمشيرة إلى ذمهم والنهي عن ملابسة أحوالهم كثيرة،

فلنقتصر على ما ذكرنا، ففيه إن شاء الله الموعظة لمن اتعظ، والثفاء لما في

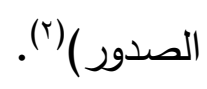

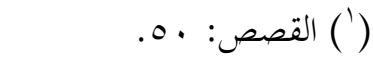

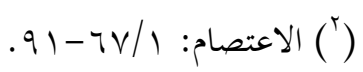

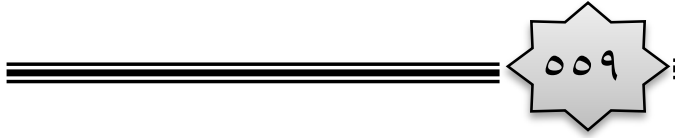


المبحث الثاني: الأدلة من السنة النبوية في الأمر بالاتباع والنهي عن

الابتداع.

تقدّمت بعض الأدلة من السنة في سياق تعسير بعض الآيات في المبحث

السابق، وفيما يلي نورد أحاديث أخرى في شأن البدعة والمحدثن لها:

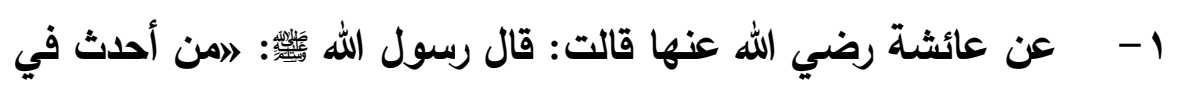

$$
\text { أمرنا هذا ما ليس منه فهو ردّه(') - (1) }
$$

$$
\text { وفي رواية: 》من عمل عملاً ليس عليه أمرنا فهو ردّه(؟). }
$$

r- عن العباض بن سارية(r) رضي الله عنه قال: صلّى بنا رسول الله ذات يوم ثم أقبل علينا فوعظنا موعظة بليغة ذرفت منها العيون، ووجلت منها القلوب. فقال قائل: يارسول الله كأن هذه موعظة مودع فماذا تعهة إلينا؟ قال: (أوصيكم بتقوى الله والسمع والطاعة وإن عبداً حبثياً، فإنه من

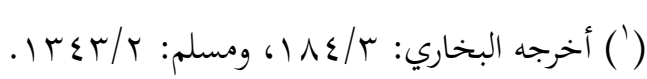

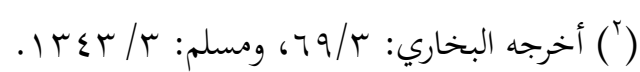

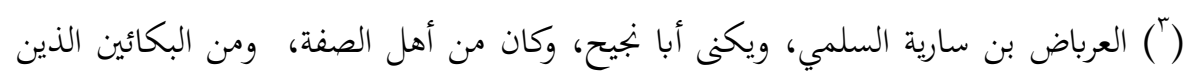

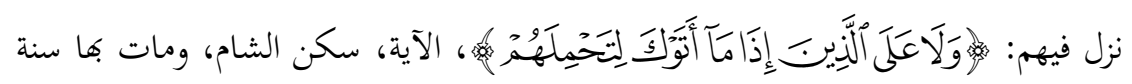

$$
\text { م V وقيل: بل مات في فنتة الزبير. }
$$

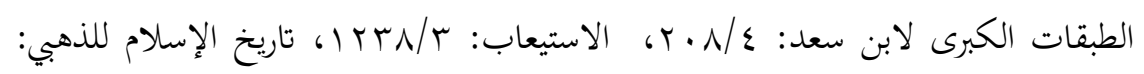

$$
\text { r }
$$


يعش منكم فسيرى اختلافاً كثيراً، فعليكم بسنتي وسنة الخلفاء المهديين الراشديين، تمسكوا بها وعَضُوا عليها بالنواجذ، وءاياكم ومحدثات الأمور،

\section{فإن كل محدثة بدعة، وكل بدعة ضلالة)(').}

r- وعن جابر بن عبد الله رضي الله عنه قال: كان رسول الله خطب احمّرت عيناه، وعلا صوته، واشتدّ غضبه، حتى كأنه منذر جيش يقول: اصبحم ومساكمه، ويقول: "بعثت أنا والساعة كهاتينه، ويقرن بين إصبعيه السبابة، والوسطى، ويقول: 》أما بعد، فإن خير الحديث كتاب الله، وخير الهلى هلى محم، وشر الأمور محثثاتها، وكل بدعة ضلالةه(r)، ثم يقول: 》أنا أولى بكل مؤمن من نفسه، من ترك مالا فلأهله، ومن ترك ديناً أو ضياعاً (م) فإلي وعليه". (1).

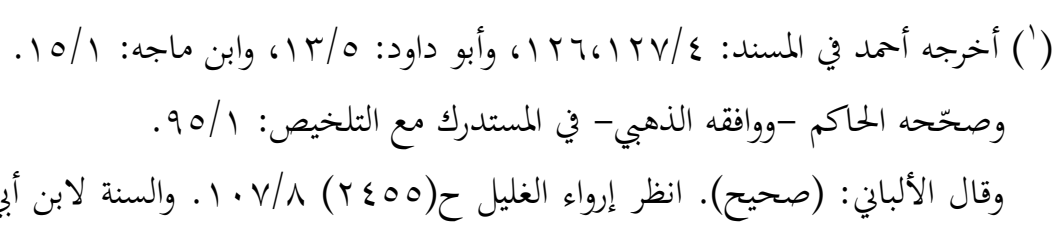
.ra/1 كما نقل تصحيح الضياء المقدسي للحديث في مشكاة المصابيح:

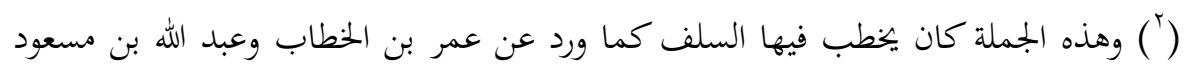

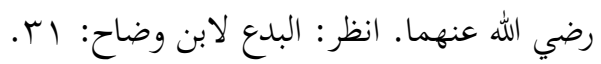
(") الضياع: أي أطفالاً وعيالاً ذوي ضياع فقضاؤه لان وضليّ.

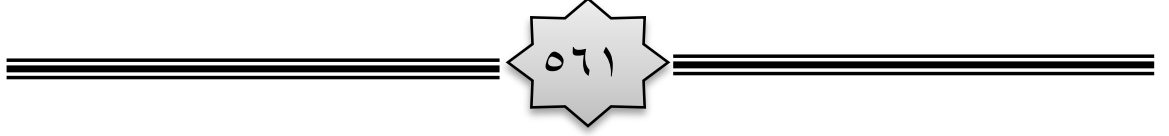


وفي رواية: لاوكل بدعة ضلالة،، وكل ضلالة في الناره(؟). ع - وعن جرير بن عبد الله بن جابر البجلي(ّ) رضي الله عنه أن رسول

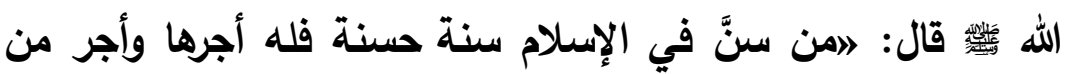
عمل بها بعده من غير أن يَنُْص من أجورهم شيء، ومن سن في الإسلام سنه سيئه كان عليه وزرها ووزر من عمل بها من بعده، من غير أن ينقص من أوزارهم شيء《(؛)، وللحديث قصة في حث النبي له الصدقة، واستجابة أصحابه رضي الله عنهم له كل حسب وسعة. ونحوها من الأحاديث الواردة في هذا الثأن.

$$
\begin{aligned}
& \text { انظر: شرح النووي على مسلم: 100/7. }
\end{aligned}
$$

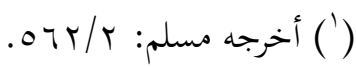

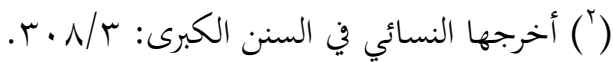

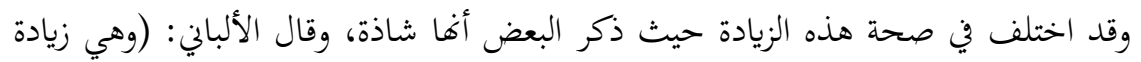

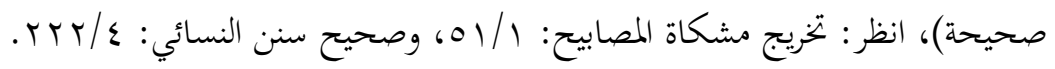

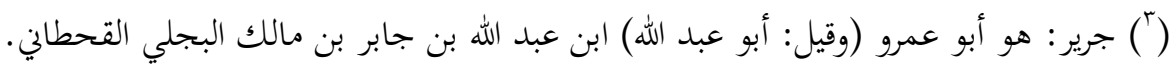
من أعيان الصحابة، وكان بديع الحسن كامل الجمال حتى لقب: (بيوسف هذه الحمبل الأمة).

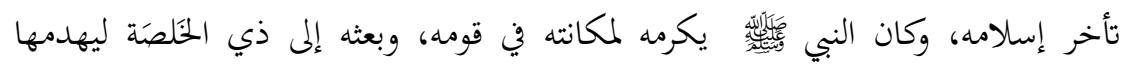

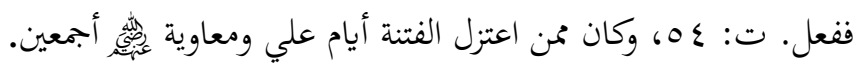

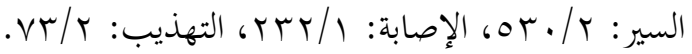

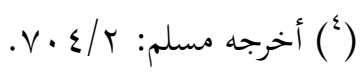


المبحث الثالث: الآثار الواردة عن الصحابة رضي الله عنه في الأمر

$$
\text { بالاتباع والنهي عن الابتداع. }
$$

$$
\text { وهي متواترة كثيرة يصعب حصرها وتعداد أفرادها، فمنها: }
$$

ما رُوي عن عمر بن الخطاب رضي الله عنه قال: (سيأتي أناس يجادلونكم بشبهات القرآن فجادلوهم بالسنن، فإن أصحاب السنن أعلم بكتاب (الله) (1)

وكان رضي الله عنه يزجر أهل البدع ويعاقبهم بمقتضى ولايته وسلطانه على المسلمين، فقد روي عنه: (أنه كان يضرب الذين يصومون رجب خوف أن يتخذ الناس سنة مثل رمضان)(؟).

وأما زجره لصبيغ البصري وضربه إياه فهي مشهورة، حيث كان صبيغ يسأل عن أشياء من القرآن وإلعلم هي من المتثابه بالنسبة له، يريد بها الفتنة وإيراد الثبه في أجناد المسلمين حتى قدم مصر فبعثه عمرو بن العاص إلى عمر رضي الله عنه فضربه بالجريد حتى تاب، ثم بعثه إلى أبي موسى لـ

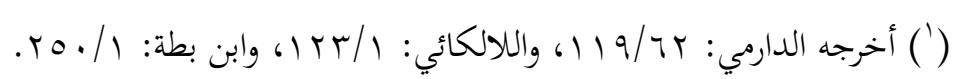

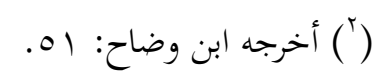


بالبصرة، وأمر بهجره، حتى إذا حسنت هيئته أذن للناس أن يجالسوه(')، وفي القصة أن عمر لما سمع به دعا الله أن يمكّنه منه. وعن عليّ بن أبي طالب رضي الله عنه قال: (ما كان رجل على رأي

$$
\text { من البدعة فتركه إلا إلى ما هو شر منه)(†). }
$$

وعن معاذ بن جبل رضي الله عنه قال: (إن من ورائكم فتنا يكثر فيها

المال، ويفتح فيها القرآن حتى يأخذه المؤمن والمنافق، والرجل، والمرأة، والصغير، والكبير، والعبد، والحر، فيوشك قائل أن يقول: ما للناس لا يتبعوني وقد قرأت القرآن؟ ما هم بمتبعي حتى أبتدع لهم غيره، فإياكم وما ابتدع، فإن ما ابتدع ضلالة، وأحذركم زيغة الحكيم، فإن الثيطان قد يقول كلمة الضلالة على لسان الحكيم، وقد يقول المنافق كلمة الحق) (). وفي رواية: (فيقراه الرجل سرا فلا يتبع، فيقول: ما أتبع، فوالله لأقرأنه علانية، فيقراه علانية فلا يتبع، فيتذذ مسجدا ويتداع كلاما ليس من كتاب

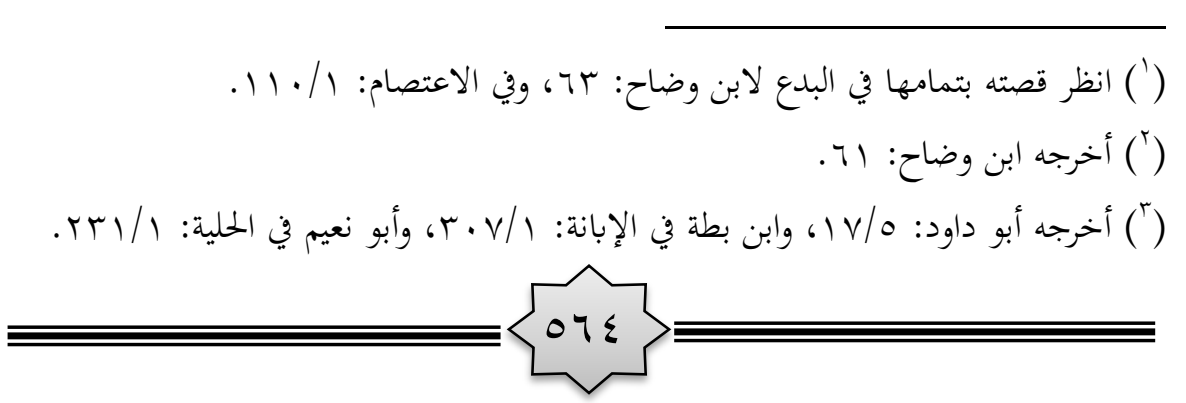


الله، ولا من سنة رسول الله وليكّة، فإياكم وإياه؛ فإنها بدعة ضلالة، وإياكم وإياه؛ فإنها بدعة ضلالة، فإياكم وإياه؛ فإنها بدعة ضلالة ثلاثاً) ('). وعنه أنه قال بالثام: (أيها الناس عليكم بالعلم قبل أن يرفع، ألا وإن رفعه ذهاب أهليه، وإياكم والبدع، والتبدع، والتنطع، وعليكم بأمركم

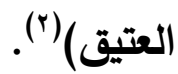

وعن عبد الله بن مسعود رضي الله عنه قال: (من أحبّ أن يكرم دينه فليعتزل السلطان ومجالسة أهل الأهواء، فإن مجالسهم ألصق من

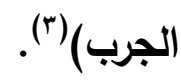

وعنه رضي الله عنه قال: (عليكم بالعلم قبل أن يقبض، وقبضه ذهاب

أهليه، عليكم بالعلم؛ فإن أحدكم لا يدري متى يفتقر إليه، أو يفتقر إلى ما عنده، وستجدون أقواما يزعمون أنهخ يدعون إلى كتاب الله وقد نبذوه وراء ظهورهم، عليكم بالعلم، وإياكم والتبدع، والتتطع، والتعمق، وعليكم بالعتيق)(؛).

$$
\begin{aligned}
& \text { (') أخرجها ابن وضاح: rس. } \\
& \text { (') المصدر السابق. } \\
& \text { (") أخرجه ابن وضاح: OV }
\end{aligned}
$$

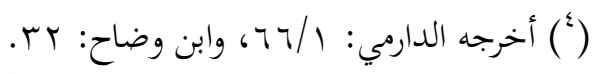


وقد أخذ بوصية ابن مسعود رضي الله عنه جمع من السلف، كالحسن

البصري أنه قال: (اعرفوا المهاجرين بفضلهم، واتبعوا آثارهم، وإياكم ما أحدث

$$
\text { الناس في دينهم، فإن شر الأمور المحدثات)("). }
$$

وكابن سيرين(؟) رحمه الله حين دخل عليه رجل من المبتدعة،

وقال له: يا أبا بكر، أقرأ عليك آية في كتاب الله، لا أزبد على أن أقرأها ثم أخرج، فوضع أصبعيه في أذنيه، ثم قال: (أحرّج عليك إن كنت مسلماً لما خرجت من بيتي)، قال: فقال: يا أبا بكر، إني لا أزيد على أن أقرأ ثم أخرج، قال: فشدّ ابن سيرين إزاره وتهيأ للخروج، فأقبل أصحابه على الرجل فقلوا: قد حرّج عليك إلا خرجت، أفيحل لك أن تخرج رجلا من بيته، فخرج، ثم قالوا: يا أبا بكر ما عليك لو قرأ آية ثم خرج؟ قال: إني والله لو ظنتت أن قلبي يثبت على ما هو عليه ما باليت أن يقرأ، ولكني خفت أن يلقي في قلبي شيئا أجها أن أخرجه من قلبي فلا أستطيع)(ّ).

$$
\overline{~(') ~(') ~ ا ٔ خ ر ج ه ~ ا ل ا ٕ م ا م ~ ا ٔ ح م د ~ ف ي ~ ا ل ز ه د: ~ ع r ب . ~}
$$

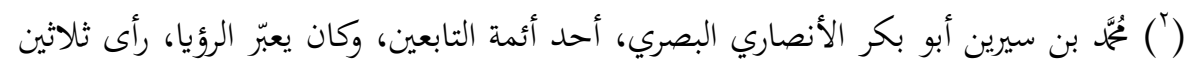

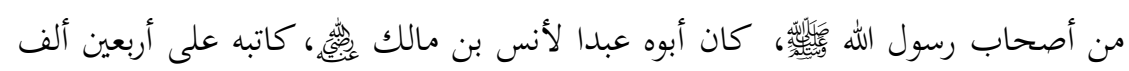

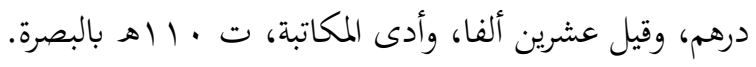

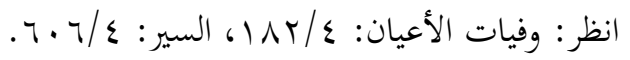

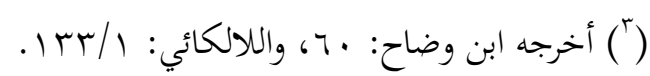




\section{وقال: (ما أحلث رجل بلدعة فراجع السنة)(').}

ومن أقوال الصـحابة رضـي الله عنهم في ذم البدع والتحذير منها ومن

أهلها قول ابـن مسعود رضـي الله عنـهـ قـال: (اتبعوا آثارنـا، ولا تبتدعوا، فقد

$$
\text { كفيتم، وكل بدعة ضلالة)(r). }
$$

وقال: (القصد في السنة خير من الاجتهاد في البدعة)(ॅ).

وعن أبي بن كعب(؛) رضي الله عنه قال: (إن اقتصاداً في سبيل

وسنة خير من اجتهاد في خلاف سبيل وسنة فانظروا أن يكون علمكم، إن

كان اجتهادا واقتصاداً، أن يكون ذلك على منهاج الأنبياء وسنتهم)(").

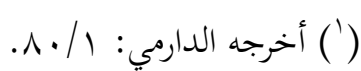

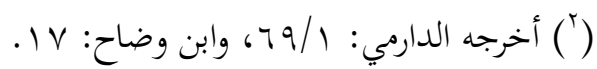

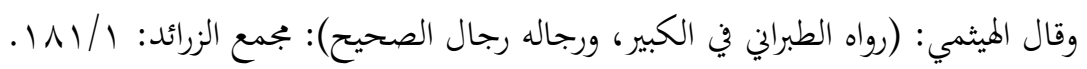

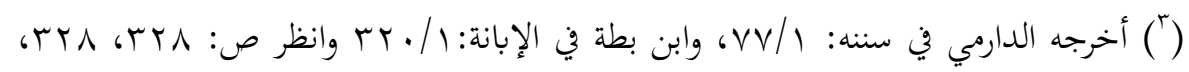

$$
\text { TON r TOV TH }
$$

وقال الحاكم في المستدرك: (هذا حديث مسند صحيح على شرطهما، ولم يخرجاه)، ووافقه

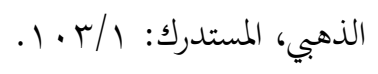

واللالكائي في شرح أصول أهل السنة: 1N/1. كلهم من قول عبد الله بن مسعود رضي الله

(") أبي بن كعب بن قيس بن عبيد الأنصاري، ، صحابي جليل، سيد القراء، ويكنأبا منذر وأبا

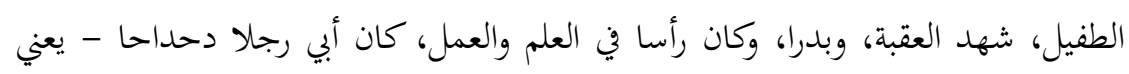

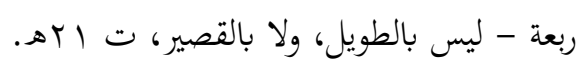


وعن حنيفة بن اليمان رضي الله عنه أنه أخذ حجرين فوضع

أحدها على الآخر ثم قال لأصحابه: (هل ترون ما بين هذين الحجرين من النور؟ قالوا: يا أبا عبد الله، ما نرى بينهما من النور إلا قليلا، قال: والذيي نفسي بيده لتظهرن البدع حتى لا يرى من الحق إلا قدر ما ترون ما بين هذين الحجرين من النور، والله لتفشون البدع حتى إذا ترك منها شيء

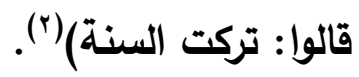
وعن عبد الله بن عمر رضي الله عنه قال: (كل بدعة ضلالة، وإن

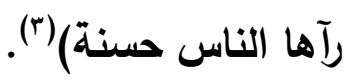
وعن ابن عباس رضي الله عنهما قال: (ما يأتي على الناس من عام إلا أحدثوا فيه بدعة وأماتوا فيه سنة , حتى تحيا البدع وتموت (السنن) (")

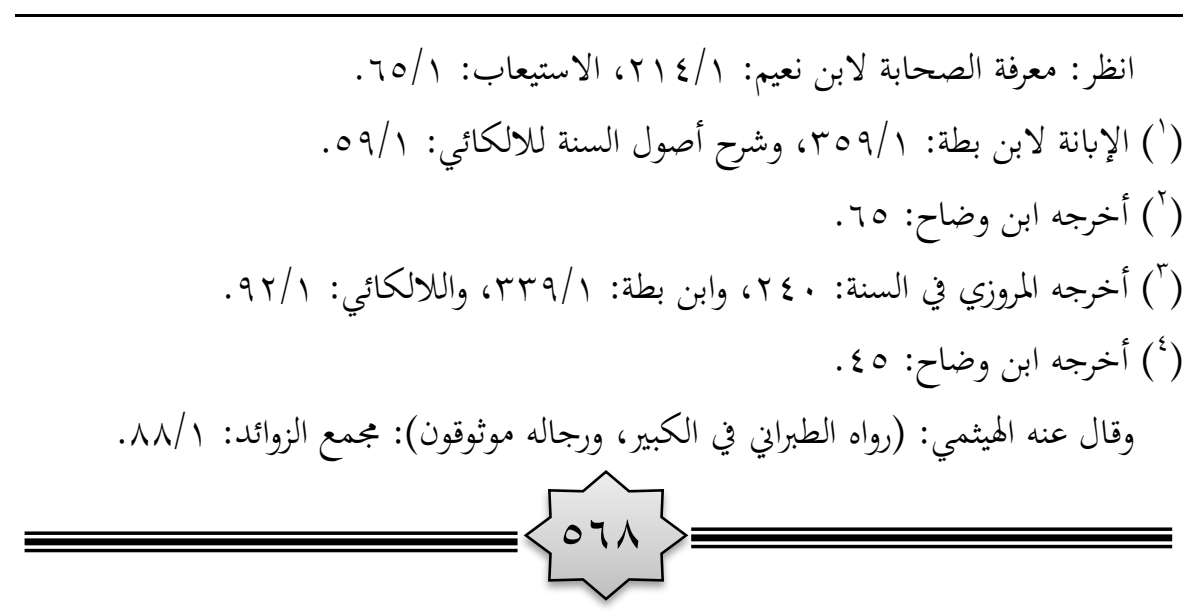


وقال له رجل: أوصني! فقال: (عليك بتقوى الله والاستقامة، اتبع

ولا تبتدع)(

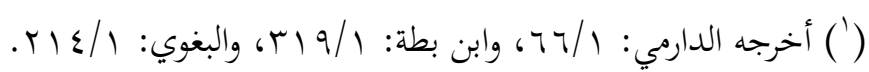

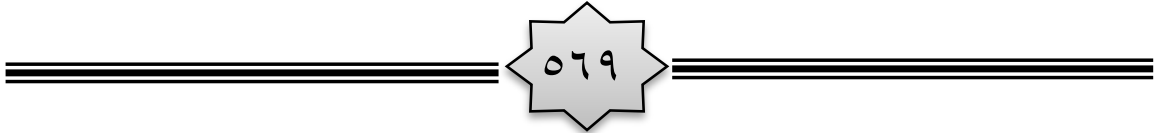


المبحث الرابع: الآثار الواردة عن السلف رحمهم الله تعالى في الأمر

$$
\text { بالاتباع والنهي عن الابتداع. }
$$

إن الآثار الواردة عن السلف الصالح في تقرير هذا الأصل كثيرة

جدّاً لا يمكن الإحاطة بها ولا حصر جزئياتها، ونذكر بعضاً منها على سبيل

التمثيل وهي تثير إلى نظائرها.

فعن هثام بن عروة(') عن أبيه(") رضي الله عنه قال: (من وقّر

$$
\text { صاحب بدعة فقد أعان على هلم الإسلام)(r). }
$$

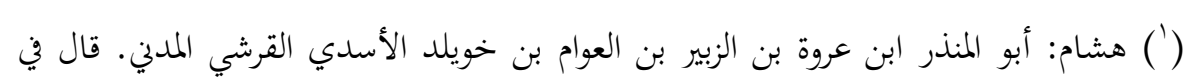

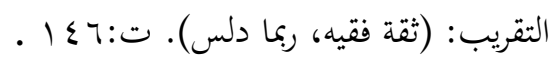

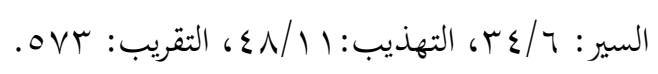

(') عروة: أبو عبد الله ابن الزبير بن العوام بن خويلد القرشي الأسدي المدني. أحد الفقهاء

$$
\text { السبعة. }
$$

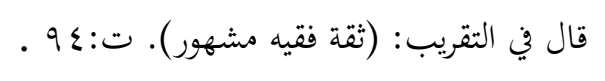

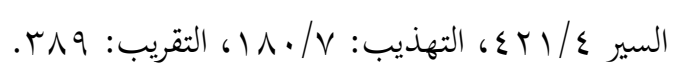

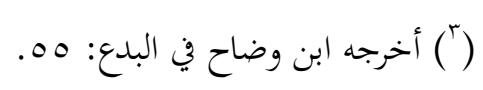

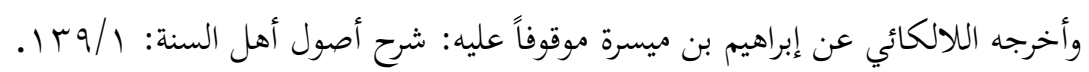

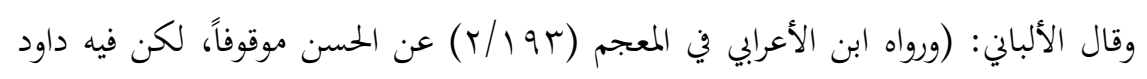

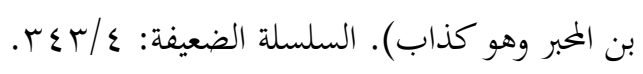

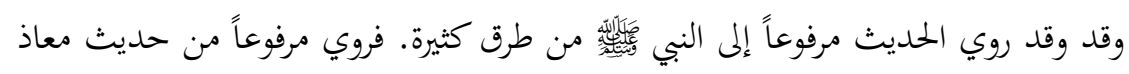

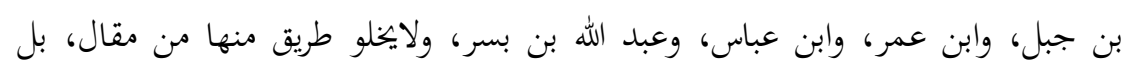

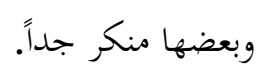


وقال أبو العالية رحمه الله: آيتان في كتاب الله ما أشدهما على

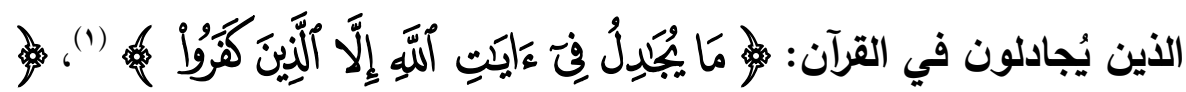

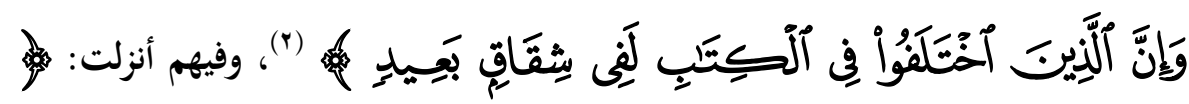

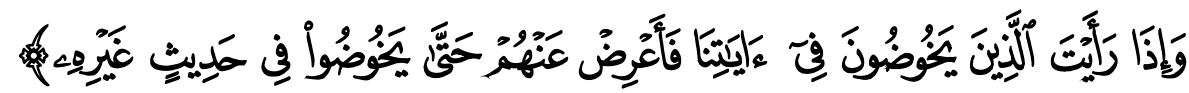

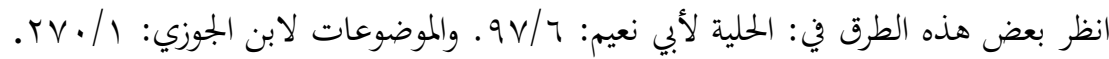

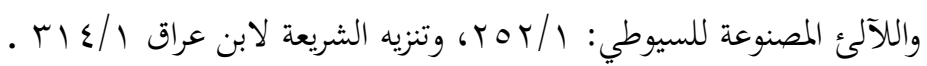

وقال الشوكاني: (إسناده ضعيف، وقال ابن الجوزي:موضوع) الفوائد المجموعة: صرئي 190 وأخرجه ابن الجوزي من طريق الحسن بن يميى الخشني عن هشام بن عروة عن أبيه عن

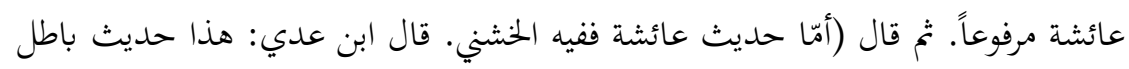
موضوع، الخشني يروي عن الثقات مالا أصل له. وقال يهيى: ليس بشيء). الموضوعات

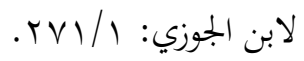

وقال الألباني: (ضعيف) السلسلة الضعيفة: ع/ • عـ ـ وأطال النفس في تخريج الحديث وتتبع طرقه، وتكلم عن بعض هذه الطرق كلاماً يفهم منه أن الشيخ كأنه يريد تحسين الحديث وقد فعل هذا -دون جزم- في تخريجه لأحاديث المشكاة. فقال عند تخريجه لهذا الحديث: (وقد رُوي موصولاً، ومرفوعاً من طرق كثيرة، يطول الكلام بإيرادها، وقد يرتقي الحديث

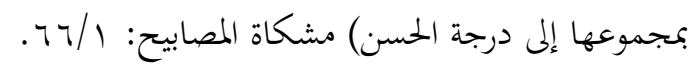

$$
\begin{aligned}
& \text { (') غافر: ع. }
\end{aligned}
$$

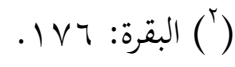

$$
\begin{aligned}
& \text { ( ) الأنعام: الأعره }
\end{aligned}
$$

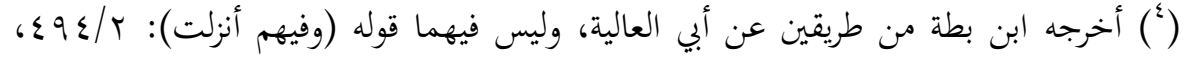

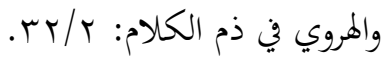

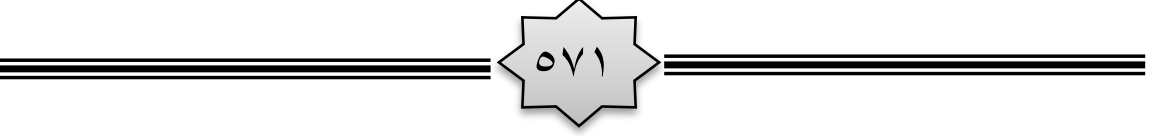


قال عمر بن عبد العزيز(') رحمه الله: (من جعل دينه غرضاً

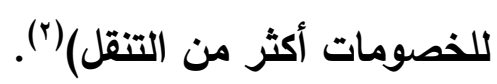

وقد قال حذيفة رضي الله عنه: (إياك والتلون في دين الله، فإن

دين الله واحد)()

وكتب رحمه الله تعالى إلى أحد ولاته: (أما بعد: أوصيك بتقوى الله،

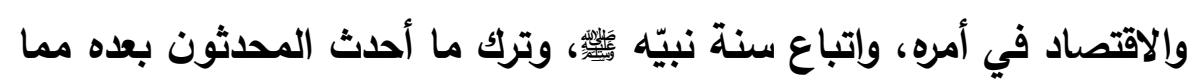
جرت به سنته وكفوا مؤنته، فعليك بلزوم السنة؛ فإنها لك بإذن الله عصمة، ثم اعلم أنه لم يبتدع الناس بدعة إلا قد مضى قبلها ما هو دليل عليها أو عبرة فيها)(؛).

(') عمر بن عبد العزيز: هو الخليفة الزاهد العابد العادل. أبو حفص ابن عبد العزيز بن مروان

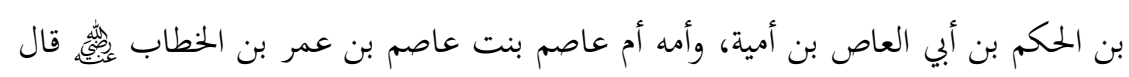

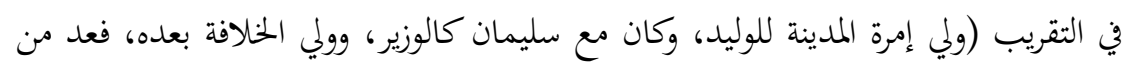

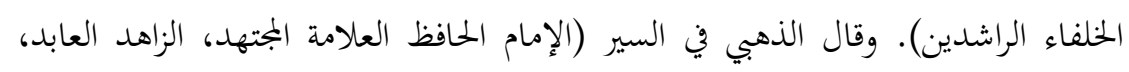

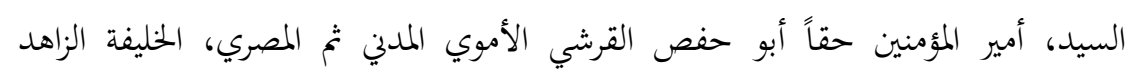

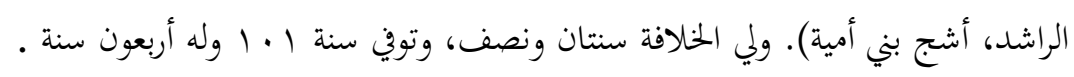

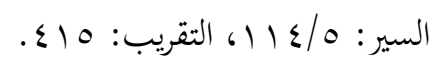

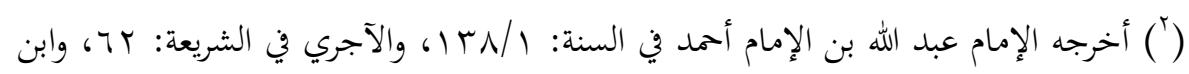

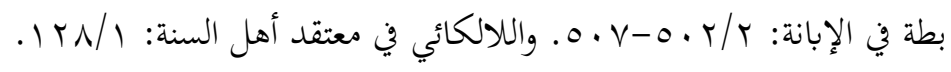

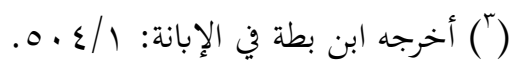

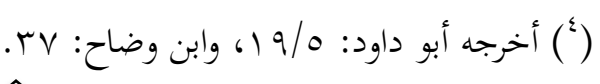
OVT 
وعن الأعمش(')، قال إبراهيم('): لا تجالسوا أهل الأهواء؛ فإن

مجالستهم تذهب بنور الإيمان من القلوب، وتسلب محاسن الوجوه، وتورث

$$
\text { البغضة في قلوب المؤمنين (ז). }
$$

وعن سفيان الثوري(؛) قال: (من جالس صاحب بدعة لم يسلم من

إحلى ثلاث: إما أن يكون فتنة لغيره، وإما أن يقع في قلبه شيء فيزل به

(') الأعمش: أبو مُمَّمَ سليمان بن مهران الأعمش الأسدي الكاهلي مولاهم الكوفي، (يُقال أهله

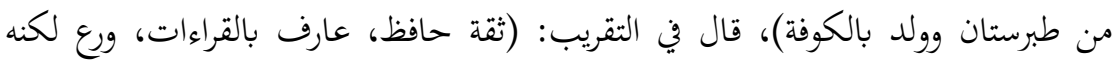

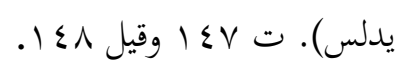

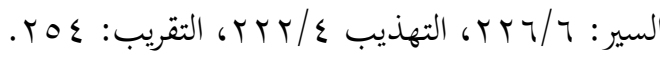

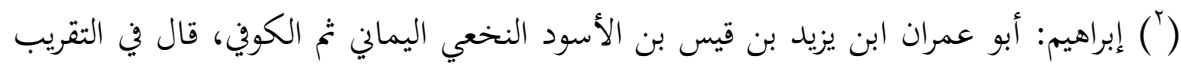

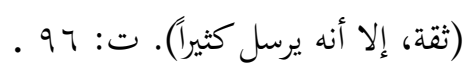

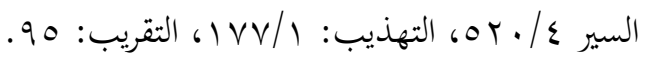

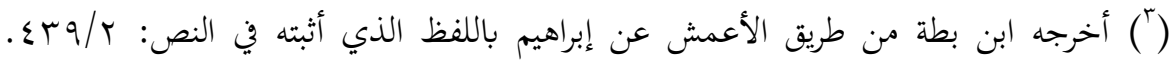

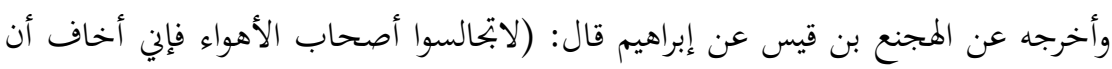

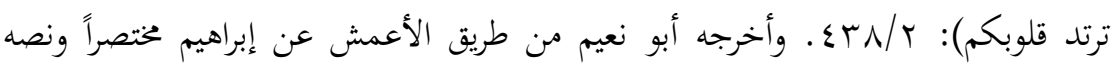

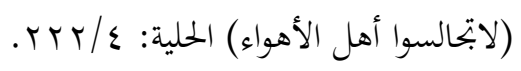

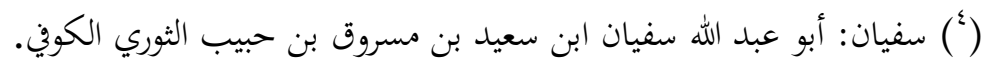

قال في التقريب: (ثقة حافظ فقيه عابد إمام حجة، من رؤوس الطبقة السابعة. وكان ربما

$$
\begin{aligned}
& \text { دلَّل) وقال في السير (هو شيخ الإسلام، إمام الحفاظ سيد العلماء في زمانه). }
\end{aligned}
$$

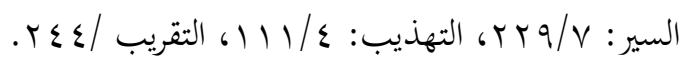

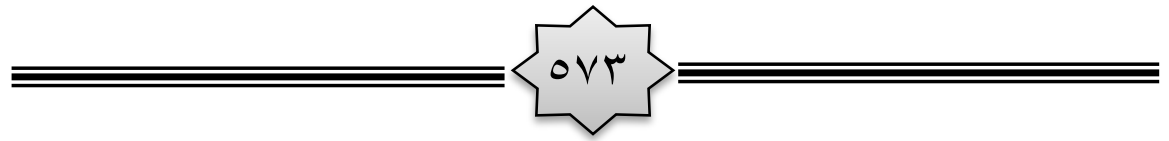


فياخله الله النار، وإما أن يقول: والله ما أبالي ما تكلّموا، وإني واثث بنفسي،

$$
\text { فمن أمن الله على دينه طرفة عين سلبه إياه)('). }
$$

وعن عبد الله بن المبارك(؟) قال: (اعلم أني أرى أن الموت اليوم

كرامة لكل مسلم لقي الله على السنة، فإنا لله وإنا إليه راجعون، فإلى الله نشكو وحشتنا، وذهاب، وقلة الأعوان، وظهور البدع، وإلى الله نشكو عظيم ما حل بهذه الأمة من ذهاب العلماء وأهل السنة، وظهور البدع)(َّ). وقال الإمام مالك رحمه الله: (إياكم والبدع)، قيل: يا أبا عبد الله، وما البدع؟ قال: (أهل البدع الذين يتكلمون في أسماء الله وصفاته وكلامه وعلمه وقدرته، ولا يسكتون عما سكت عنه الصحابة والتابعون لهم

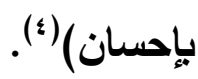

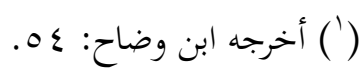

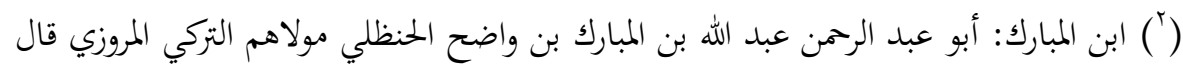

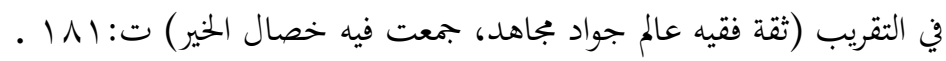

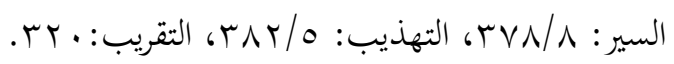

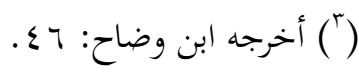

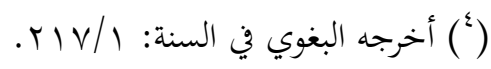


وقال أبو يوسف('): العلم بالكلام جهل، والجهل بالكلام هو

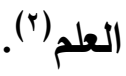

قال الذهبي: (وما أنبل قوله الذي رواه جماعة عن بثر بن الوليد

سمعت أبا يوسف يقول: ((العلم بالخصومة وإلكلام جهل والجهل بالخصومة

وإلكلام علم)) قلت: مثاله شبه وإثكالات من نتائج أفكار أهل الكلام، تورد

في الجدال على آيات الصفات وأحاديثها، فيكفر هذا هذا، وينشأ الاعتزال

والتجهم، والتجسيم، وكل بلاء نسأل الله العافية) (").

وقال الفضيل بن عياض()؛: لا تجلس مع صاحب بدعة، فإني

أخاف أن تنزل عليك اللعنة(1).

(') أبو يوسف: يعقوب بن إبراهيم بن حبيب بن حُبَيش البجلي حليف الأنصار الكوفي. قال

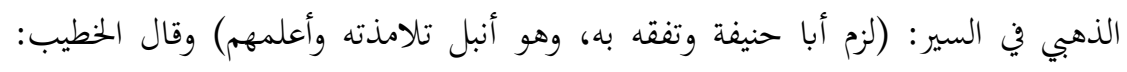

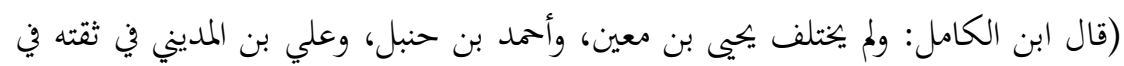

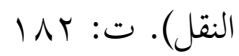

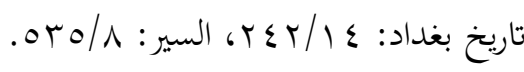

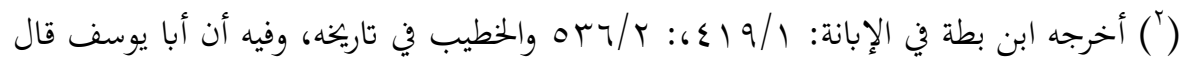

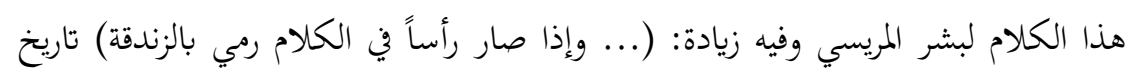

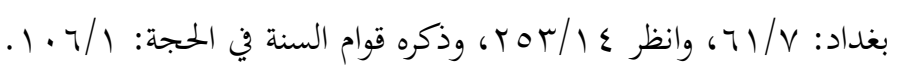

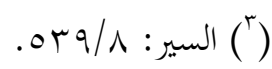

(") الفضيل: أبو علي ابن عياض بن مسعود بن بِشْر التميمي مولاهم المكي خراساني الأصل-

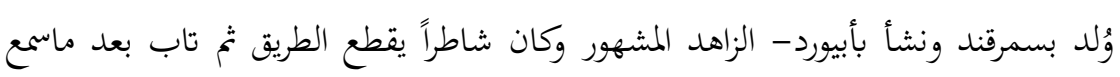

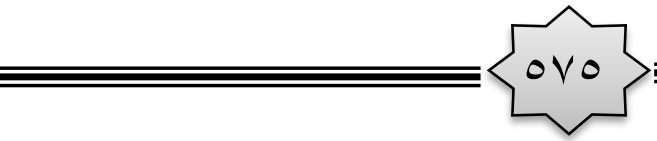


وقال أيضاً: صاحب البدعة لا تأمنه على دينك، ولا تثاوره في

أمرك، ولا تجلس إليه، فإنه من جلس إلى صاحب بدعة ورّثذه الله العمى(؟). وقال عبد الله بن الإمام أحمد(ّ): سمعت أبي يقوا: كان الشافعي رحمه الله إذا ثبت الخبر عنده قلّه، وخير خصلة فيه لم يثتهي الكلام، إنما همته الفقه(๕). وعن الربيع بن سليمان(')، قال الثافعي رحمه الله: لأن يلقى الله العبد بكل ذنب ما خلا الثرك باله خير لله من أن يلقاه بثيء من

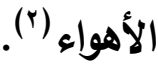

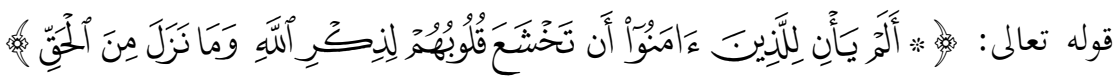

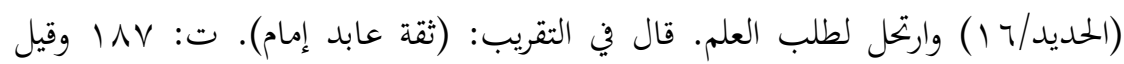
قبلها.

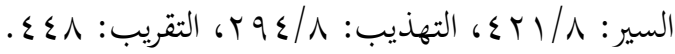

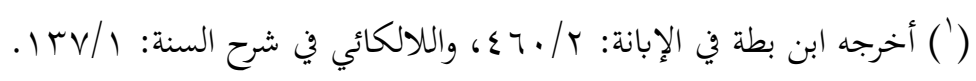

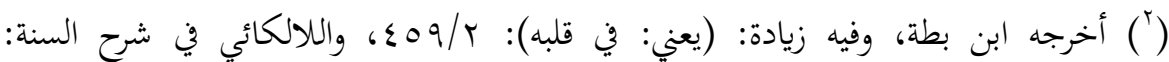

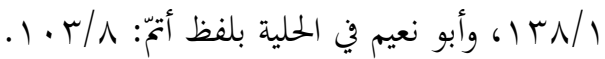

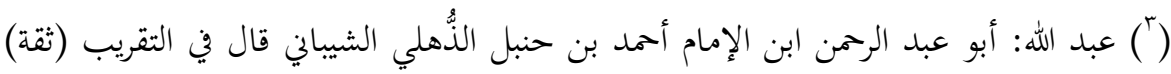
ت

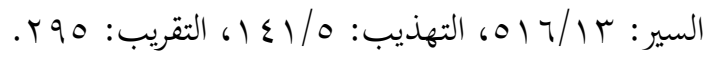

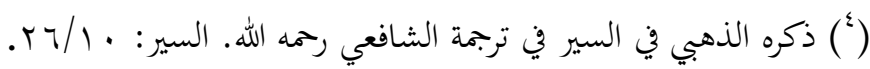


وعن الحسين بن علي(r) قال: سمعت الثافعي يقول: حكمي في

أصحاب الكلام أن يضربوا بالجريل، ويحملوا على الإبل، ويطاف بهم في العشائر والقبائل، وينادى عليهم: هذا جزاء من ترك الكتاب والسنة وأخذ في

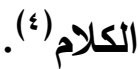

(') الربيع: أبو مُحَّم ابن سليمان بن عبد الجبار بن كامل المؤذن المرادي مولاهم المصري قال في

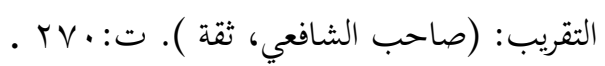

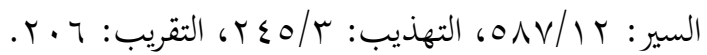

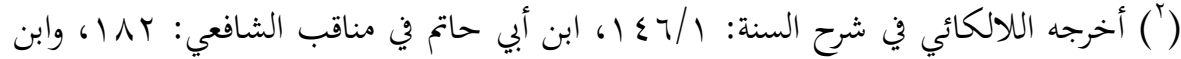

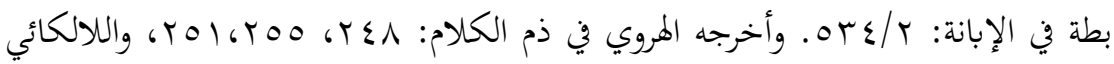

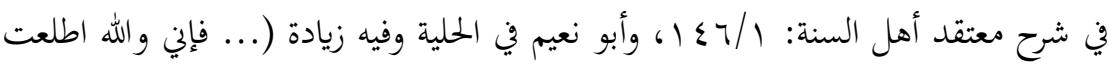

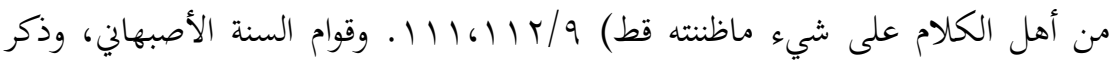
سبب قول الشافعي لهذا الكلام وأنه قاله بعدما ناظر حفصاً الفرد المرجئ المتكلم المبتدع.

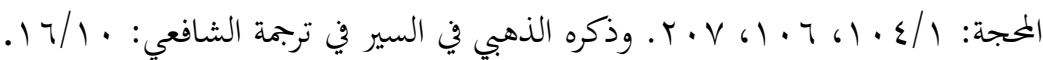
وقد ناظر الشافعي حفصاً في مسألة خلق القرآن وكفره لقوله بخلق القرآن.

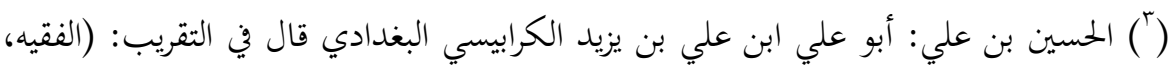

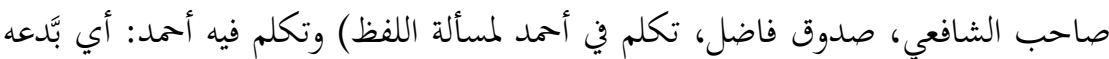

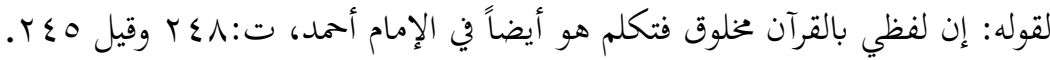

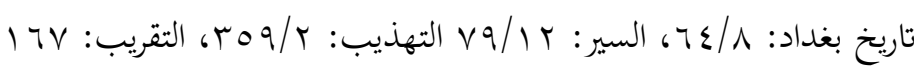
ملاحظة:- ذكره الحافظ في التهذيب وتقريبه تمييزاً له.

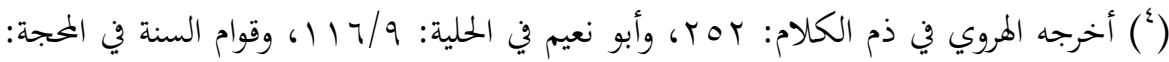
. $r \cdot N / 1$

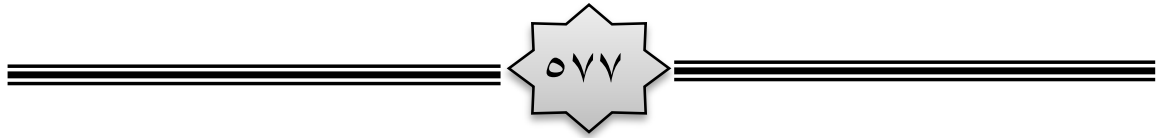


وعن عبد الرزاق(') قال: قال لي إبراهيم بن عحمل بن أبي يحيى(ץ): أرى المعتزلة عندكم كثيراً، قال: قلت: (نعم، وهم يزعمون أنك منهم!)، قال:

(') عبد الرزاق: أبو بكر ابن همام بن نافع الصنعاني الحميري مولاهم قال في التقريب: (ثقة

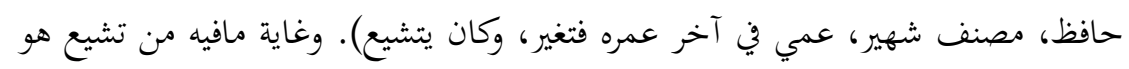

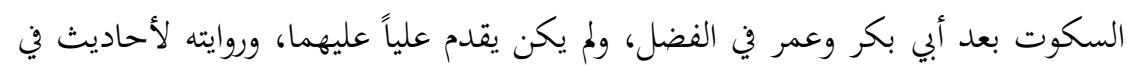
فضائل أهل البيت يوافق عليها، وكان يعرض بمعاوية رضي الله عن الصحابة أجمعين. ت:ITR

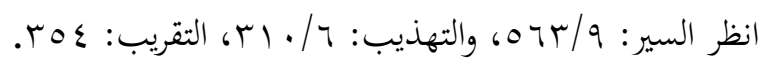

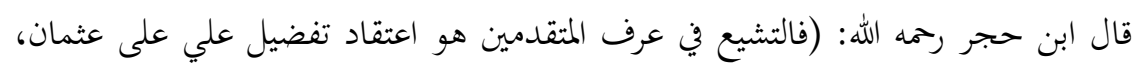

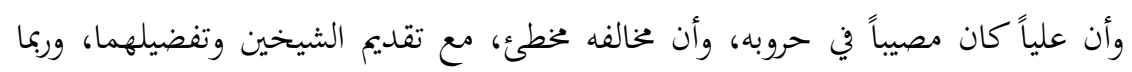

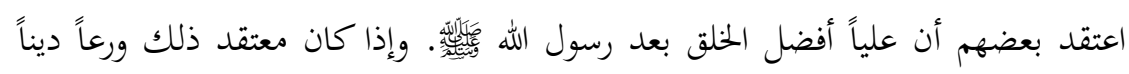

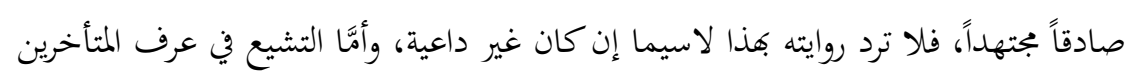

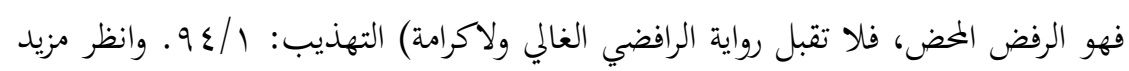

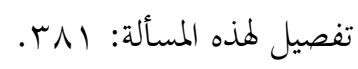

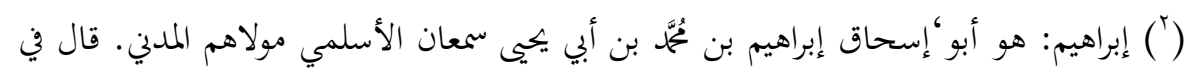

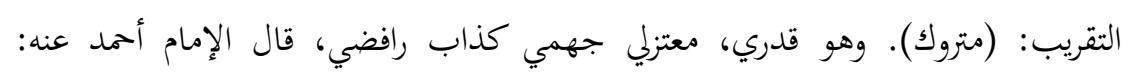

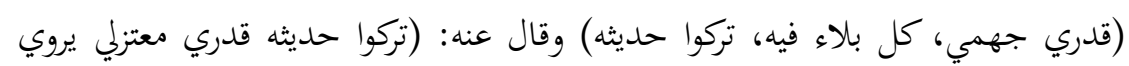

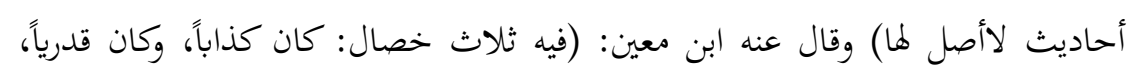

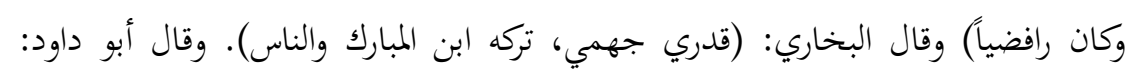

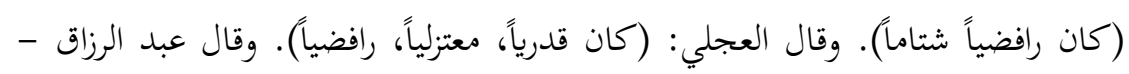

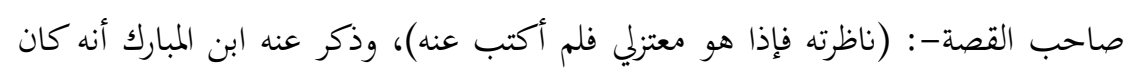

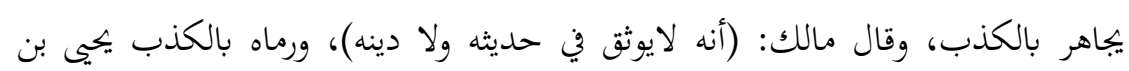

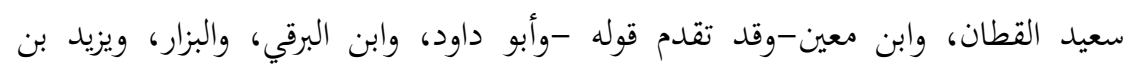

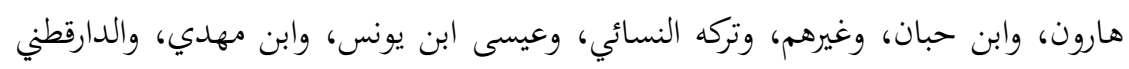

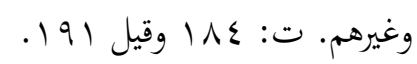

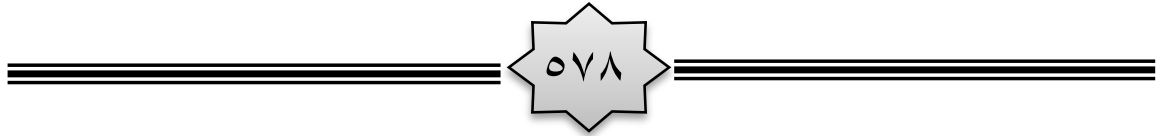


أفلا تلخل معي هذا الحانوت حتى أكلّمك؟ قلتُ: لا. قال: لـ؟ قلت: (لأن

\section{القلب ضعيف والدين ليس لمن غلب)(").}

وكان (ابن طاووس(r) جالساً فجاء رجل من المعتزلة(r) فجعل يتكلم،

قال: فأدخل ابن طاووس أصبعيه في أذنيه، قال: وقال لابنه: (أي بني أدخل أصبعيك في أذنيك واشدد، ولا تسمع من

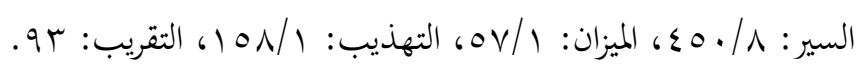

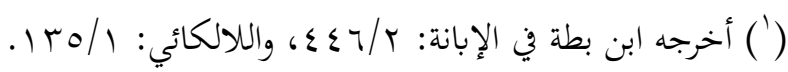

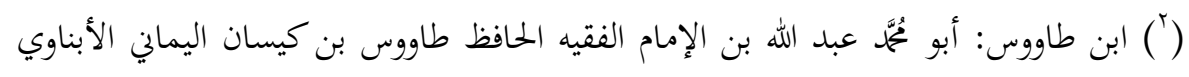

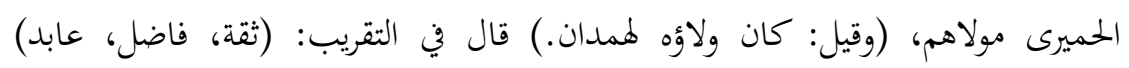
تש:Tr

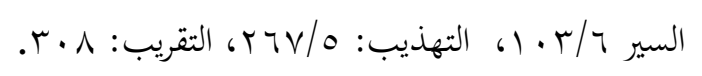

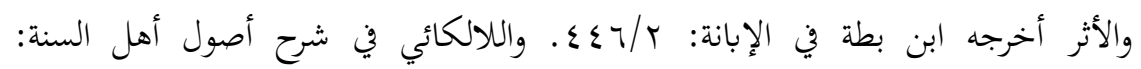

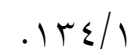

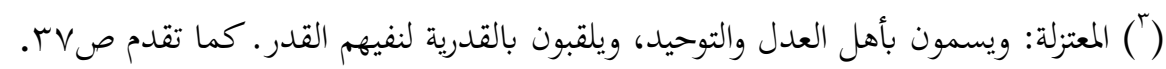

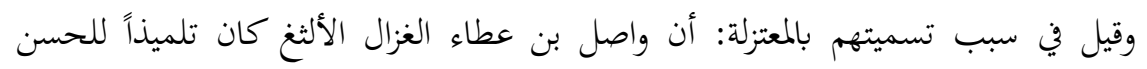

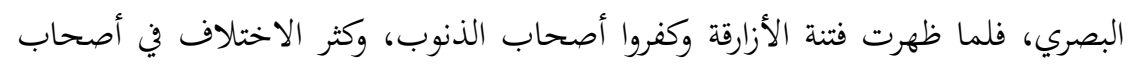

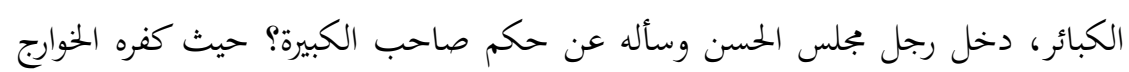

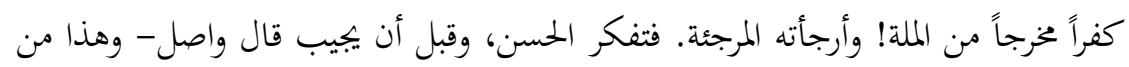

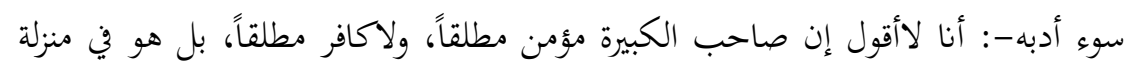

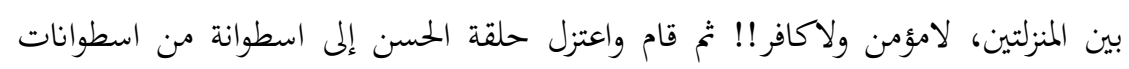

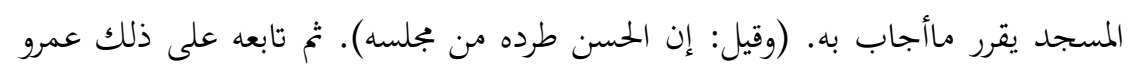

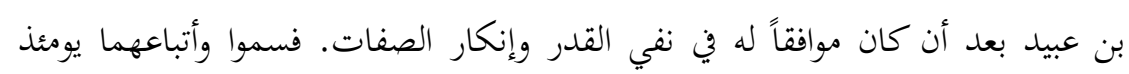
بالمعتزلة، لاعتزالمم حلقة الحسن وقول الأمة .

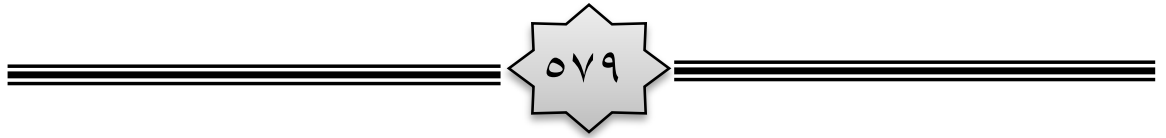




\section{كلامهه شيئًا. قال معمر : يعني: أن القلب ضعيف)(').}

وجاء رجل إلى يونس بن عبيد(؟)، فقال لـه: يـا أبا عبد الله تنهانـا عن مجالسة عمرو بن عبيد(ז) وقد دخل عليه ابنك؟ قيل: قال: ابني؟ قال: نعم،

وهم فرق كثيرة تصل إلى مايقارب من عشرين فرقة تقريباً، كل فرقة تكفر سائرها، ومن أشهر

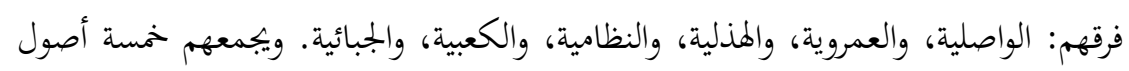
ا - العدل: ويموها الأصول الخمسة وهي:

r - بالتوحيد: ويريدون به نفي الصفات. ومن فروعه القول بخلق القرآن - وقد امتحنوا الناس بها

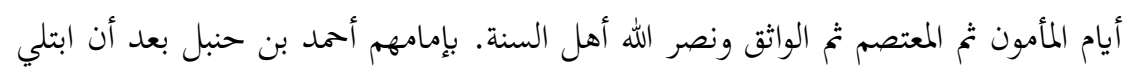
بلاءً شديداً.

r -والمنزلة بين المنزلتين: أي أن الفاسق يخزج من الإسلام ولايدخل في الكفر وبتري عليه أحكام الإسلام في الدنيا!!

ع -والوعد والوعيد: ويريدون به تخليد الفاسق في النار في الآخرة كما يخلد المؤمن الطائع في

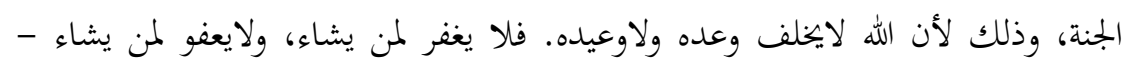

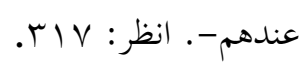

ه -والأمر بالمعروف والنهي عن المنكر: : ويريدون به الخروج على الحكام وإشهار السيف عليهم.

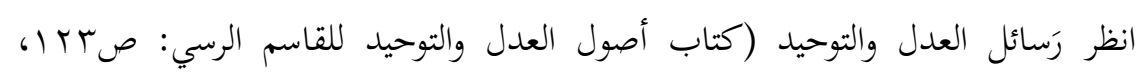

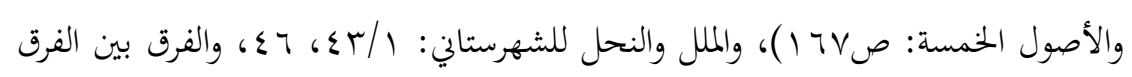

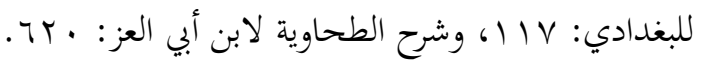

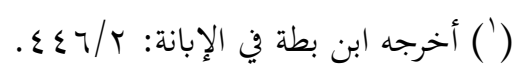

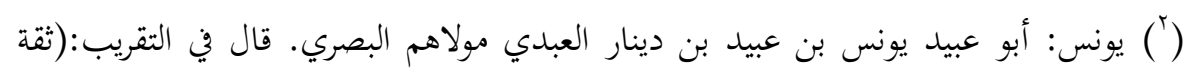

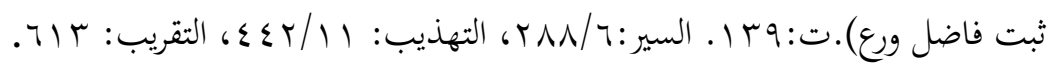

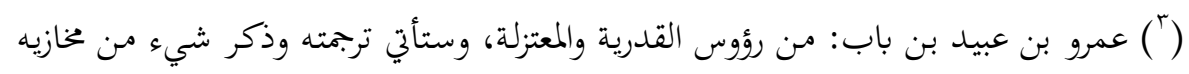

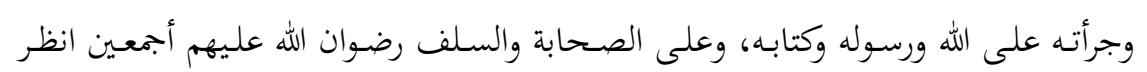


قال: فغيظ الشيخ، قال: فلم أبرح حتى جاء ابنه، فقال: يابني قد عرفت رأيي في عمرو ثم تدخل عليه (')! قال: كان معي فلان وجعل يعتذرُ . فقال يونس: أنهاك عن الزنا والسرقة وشرب الخمر، ولأن تلقى الله بهن أحب إلي من أن تلقاه برأي عمرو وأصحاب عمرو (r). وقال ابن شوذب رحمه الله(ّ): (عليكم بالسنة والحديث، وماينفعم الله به، وإياكم وإلخوض والجدال وإلمراء، فإنه لايفلح من أحب الكلام، وكل من أحدث كلاماً لم يكن آخر أمره إلاًّ إلى بدعة، لأن الكلام لايدعو إلى خير. صاץY. (') ورأيه في عمرو هو هجره وترك السلام عليه لبدعته. أخرج الخطيب وابن عدي عن حماد بن

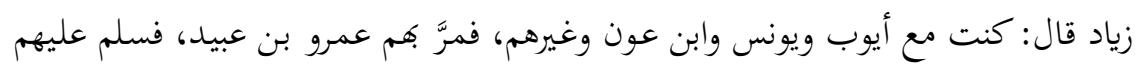
ووقف وقفة، فما ردوا عليه، ثم جاز فما ذئ ذكروه.

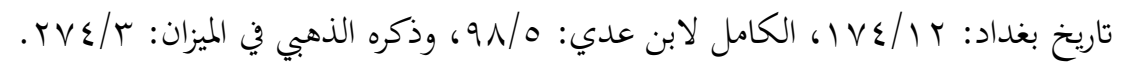

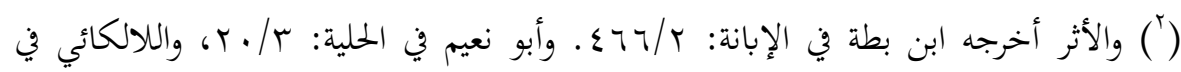

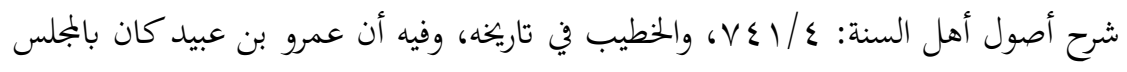

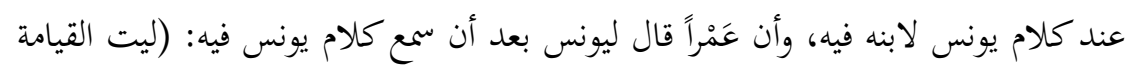

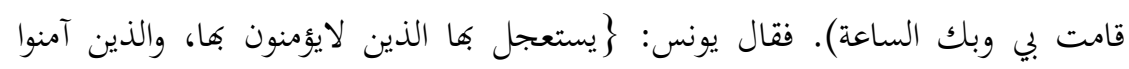

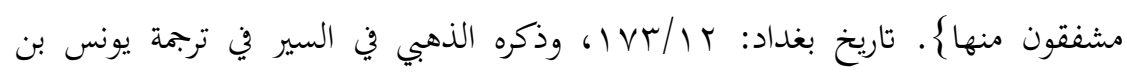

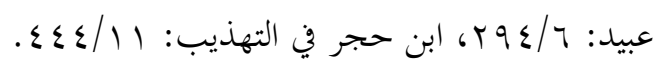

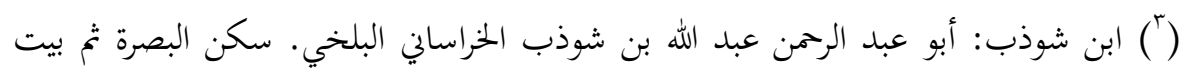
المقدس .

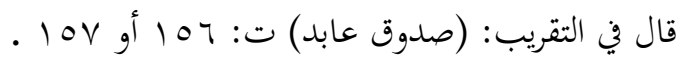

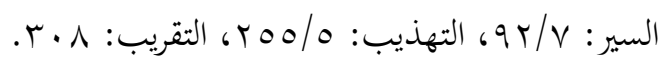

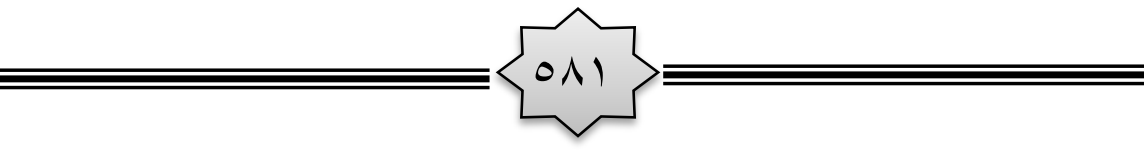


وعليكم بالسنن والآثار والفقه الذي تنتفعون به، ودعو الجدال وكلام أهل الزيغ والمراء، أدركنا الناس ولايعرفون هذا ويجانبون أهل الكلام، وعاقبة الكلام لاتؤول إلى خير، أعاذنا الله وإياكم من الفتن، وسلمنا وإياكم من كل هلكة) (')

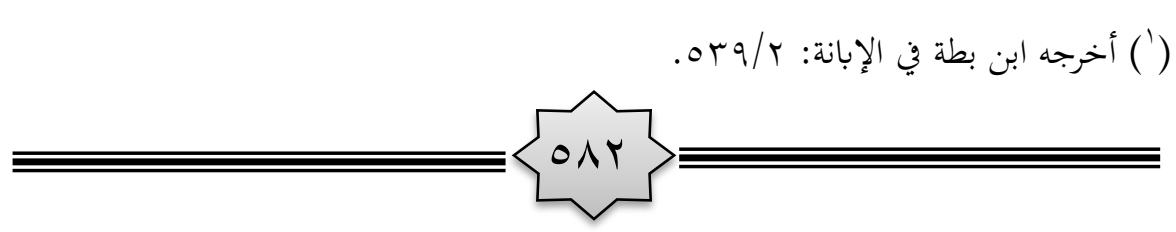




\section{المبحث الخامش : مراد السلف من التغليظ على أهل الأهواء والبدع.}

إن ما تقدّم من روايات كثيرة عن أئمة السلف - وما تركناه أكثر -

في التشنيع على أهل الأهواء والتغليظ على أهل البدع يجب أن لا نغفل فيه عن ثلاثة أمور مهمة لفهم مرادهم من هذا الموقف، وهي: الأول: إن الآيات الواردة في الأمر بالتمسّك بثرع الله وتحكيمه، وتنهى عن القول في دين الله بغير علم والإحداث فيه، وتأمر بالاعتصام بحبل الله، وأن لا يتفرّقوا كالذين من قبلهم فيصبحوا شيعاً وأحزاباً كل حزب بما لايهم فرحون، إنما نزلت في شأن المؤمنين ومن يقابلهم من أهل الكتاب والمشركين والمنافقين.

وأما ما ورد عن بعض السلف بتفسير بعض الآيات بأهل البدع والأهواء، أو حمل مدلولاتها عليهم، أو ما ذكر عنهم أنها نزلت في طوائف منهم، إنما هو تفسير للآية ببعض ما تلّّ عليه، وبذكر أمثلة يتضح بها

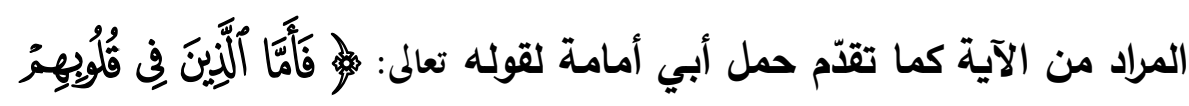

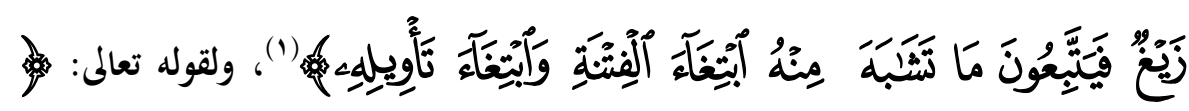




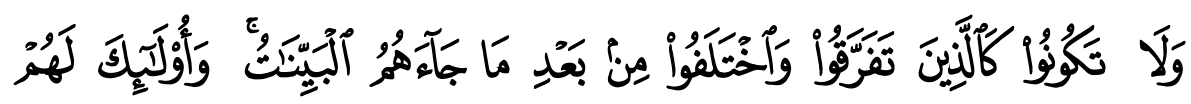

عَذَابُ عَظِيمر هُ (1) ، أنه حملها على الخوارج، فمراده شمول هذه الآية لكل

من اتصف بهذه الصفات ومنهم الخوارج.

ونحو هذا ما نقل عن ابن عباس رضي الله عنهما والحسن والإمام

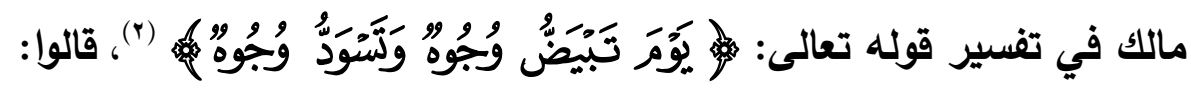
تبيض وجوه أهل السنة، وتسودّ وجوه أهل البدعة.

وهذا كثير من كلام السلف رضي الله عنهم في تفسير القرآن

وكنلك يقال في الأحاديث النبوية الواردة في هذا الثأن فإنها في

مجملها تأمر بالتمسّك بكتاب الله وسنته، والاجتماع على شرعه، وإحياء ما اندثر منها، وتحذّر من الفرقة والاختلاف والإحاث في دين الله، وتبيّن أن هذا هو شأن من قبلنا من الأمم التي ضلّت عن دين الله وصراطه المستقيم، وبعضها فيها ذكر صريح لأهل الأهواء والخصومة في الدين، والمراء بغير حق، واتباع المتشابه ابتفاء الفتنة.

$$
\text { (') آل آل عمران: } 1 \text { (1) } 1 \text { (1) }
$$


ولم يرد فيها ذكر لفرق بعينها سوى ما خرج عن الخوارج الذين

ظهرت بذرة شجرتهم الخبيثة في عهل النبوة، واعتدى جدّهم على مقام النبوة

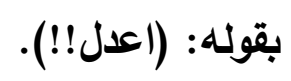

ثم امتدت جذورها، وطال مساقها، وأثمرت عند اشتداد الفتن بعد

الخليفة الراشد عثمان بن عفان رضي الله عنه في عاصمة الدولة الإسلامية(')، مستقلة مفارقة لجماعة المسلمين، حيث ظهرت كفرقة مستقلة مفارقة للجماعة لها أصول وعقائد ومنهج الاستدلال خاصة بها في عها عليّ رضي الله عنه حتى خرجوا عليه بعد واقعة صفين، فقتلهم في النهروان، وتفرّق بعض قادتهم في الأمصار ينشرون فكرهم لاى العامة

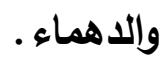

فهم أول الفرق ظهوراً، ولهذا صحّت الأحاديث فيهم بذكر كثير من

صفاتهم بدقة، ولكن دون التصريح بلقبهم المشهور (الخوارج أو الحرورية)

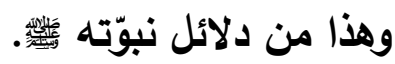

$$
\begin{aligned}
& \text { (') انظر: كتاب العواصم من القواصم لابن العربي المالكي، وكتاب السبئية لسليمان العودة، }
\end{aligned}
$$

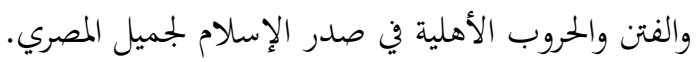

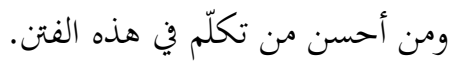

$$
\begin{aligned}
& \text { o } 10
\end{aligned}
$$


وأما ما ورد من الأحاديث بذكر الرافضة أو القدرية أو المرجئة،

فكلها أحاديث لا تخلو أسانيدها من مقال، بل يمكن الحكم على متنها بالنكارة، والله أعلم.

الثاني: واقع الأمة وأحوال المبتدعة في القرون الأولى المفضّلة.

إن الآثار التي وردت عن السلف الصالح في الإغلاظ على الباع

وأهلها بالقول والفعل إنما صدرت منهم وهم يعيثون فجر الإسلام، حيث

القرون الأولى التي هي خير قرون الأمة، بل هي خير قرون البشرية كلها، والمسلمون كلهم على التوحيد والسنة -في الجملة- وأهل الباع في قلة بحيث لا تكاد تذكر نسبتهم لعموم الأمة.

عن عبد الله بن مسعود رضي الله عنه، عن النبي قال: اخير الناس قرني، ثم الذين يلونهم، ثم الذين يلونهم، ثم يجيء أقوام تسبق شهادة أحدهم يمينه، ويمينه شهادتهـ('). قال النووي رحمه الله: (الصحيح أن الأول: قرنه والثاني: التابعون، والثالث: تابعوهم)(؟). وكانت الغلبة والسلطان حينئ لاينه وشرعه وسنة نبيّه

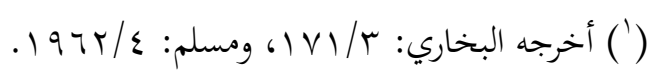

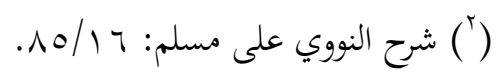


المأمون والمعتصم والواثق من قبل الجهمية كانت الغلبة والسلطان في عموم

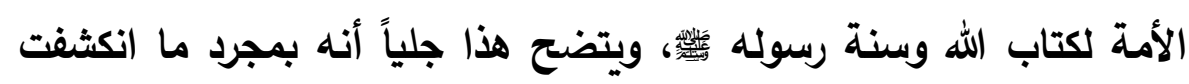
الفتنة، وعادت الاولة سريعاً لمذهب أهل السنة في عهد المتوكل، وإذا بالأمة في مجملها ما زالت على دين الله وفطرته التي فطر الناس عليها. وقد ذكرت كتب التاريخ والسير كيف أضحى أئمة الجهمية منبوذين مهجورين من الناس، ضربت عليهم الألة والمسكنة، كما ذكرت كتب المصادر كيف اجتمعت الأمة بعد ذلك حول الإمام أحمد وعلماء السنة، حتى إنه كان يأمر من بغداد بهجر أناس في خراسان فينفّ أمره. ولهذا قال الإمام أحمد بكل ثقة: (قولوا لأهل الباع: بينتا وبينكم يوم الجنائز حين تمر)، فهو بهذا القول أراد الإثارة إلى أن الأمة في مجملها في وقته ما زالت على الفطرة وعلى ما يقوله أئمة السنة، وإن الجهمية لا قبول إلا لان قليل ممن شذّ وفارق الجماعة، وقد تحقّق قوله هذا حيث توفي رحمه الله عام (1 أهـ) فإنه حضر غسله نحو مائة من بين الخلافة من بنيى هاشم، وخرج الناس بنعشه من الرجال والنساء ما لم يعلم عددهم إلا الله، حتى إنهم حزروا بألف ألف (مليون إنسان)، ومنهم من حزهم (سبعمائة ألف) سوى من كان في سفن دجلة ببغداد، وقيل: إنه لم

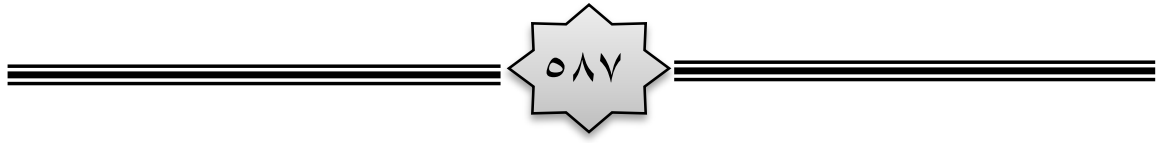


يجتمع مثل هذا العدد في جنازة أي إنسان قبله، وأسلم يوم موته: عشرون

\section{ألفاً من اليهود وإلنصارى وإلمجوس(').}

قال ابن كثير -بعدما ذكر قول الإمام أحمد هذا-: (صدق الله قوله

في هذا فإنه رحمه الله كان إمام السنة في زمانه، وعيون مخالفيه أحمد بن

أبي دؤاد وهو قاضي قضاة الدنيا لم يحتفل أحد بموته ولم يلتفت إليه، ولما

مات ما شيعه إلا قليل من أعوان السلطان)(•).

وبناءً عليه فإنه لا ينبفي أن يعن التحدّي بيوم الجنائز لأهل

البدع في مكان أو زمان يكونون فيه هم الأكثر والأغلب، وأهل السنة هم الأقل والأضعف بل ربما كانوا أقلية مغلوبة، ولا وجود لهم يذكر، لا في الدولة ولا عند جماهير الناس، بل إنه يجب مراعاة فقه الواقع هذا حتى مع غير المسلمين، فالتعامل مع أهل الكفر والثرك حال الغلبة وإلظهور والتمكين يختلف عنه في حال القهر والضعف والهزيمة.

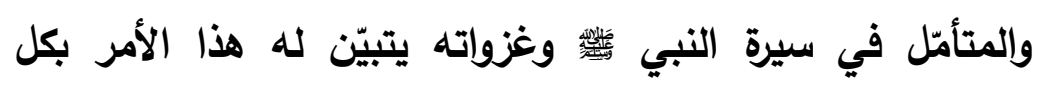
وضوح وجلاء، بل إن شيخ الإسلام ابن تيمية بيّن أن النبي كان يحب مرافقة أهل الكتاب فيما لم يؤمر به في صدر الهجرة، ثم نسخ ذلك واستقر

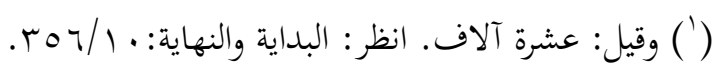
(') المصدر السابق. 
الأمر على مخالفة الكفار والنهي عن التثبّه بهم بجميع أصنافهم ثم قال: (وسبب ذلك: أن المخالفة لهم لا تكون إلا مع ظهور الدين وعلوه كالجهاد، وإلزامهم بالجزية والصغار، فلما كان المسلمون في أول الأمر ضعفاء؛ لم تثرع المخالفة لهم، فلما كمل الدين وظهر وعلا؛ شرع بذلك. ومثل ذلك اليوم: لو أن المسلم بدار حرب، أو دار كفر غير حرب؛ لم يكن مأمورا بالمخالفة لهم في الهاي الظاهر، لما عليه في ذلك من الضرر بل قـ يستحب للرجل، أو يجب عليه، أن يشاركهم أحيانا في هليهم الظاهر، إذا كان في ذلك مصلحة دينية: من دعوتهم إلى الدين، والاطلاع على باطن أمرهم لإخبار المسلمين بذلك، أو دفع ضرهم عن المسلمين، ونحو ذلك من

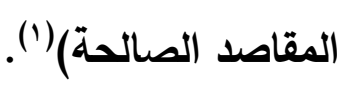
الثالث: حال المبتدعة الذين غلظ السلف عليهر.

إن الآثار الواردة عن السلف في ذم إهل البدع والتبرؤ منهم ومن عقائدهم، وهجرهم والإغلاظ عليهم، ومعاقبتهم بشتى أنواع العقوبات إنما كانت في بدايات نشوء مقالات أهل البدع، أي: في مرحلة تأسيس الفرق، ولم تكن قد شاعت هذه الفرق في كثير من الناس، ولا انتشرت مقالاتهم في

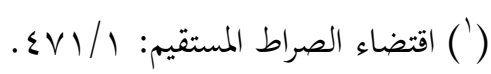


الأمة، بخلاف ما حدث بعد ذلك في القرون المتأخّرة حيث تسرّب كثير من مقالات أهل البدع ولوازم مذهبه إلى كثير من الناس، ومنهم من هو من أهل الخير والصلاح، وربما كانوا من العلماء وأئمة الدين، فلا يجوز أن نحمل الأقوال الواردة عن السلف على أمثال هؤلاء، فكثير من عبارات السلف الغليظة في المبتدعة إنما كان عن المؤسّسين لهذه المقالات الفاسدة والفرق الضالة، وعن الأئمة الضالين المضلين، المنظرين لها والداعين إليها. والناظر لحال كثير من مؤسّسي هذه الفرق في صدر الإسلام يتبيّن له أنهم امتداد لكبيرهم عبد الله بن سبأ الحميري اليهودي، الذي أراد تكرار نموذج (شاؤل اليهود، أو الرسول بولس المسيحي) الذي نجح في إفساد النصرانية من داخلها، وتفريغ جوهرها ومحتواها إلى خرافات وطقوس ما أنزل بها من سلطان، فنجح عبد الله بن سبأ في إفساد بعض المسلمين، ونسي أن الله تكفّل بحفظ دينه('). (') انظر : عبد الله بن سبأ اليهودي وأثره في إحداث الفنتة لسليمان بن فهد.

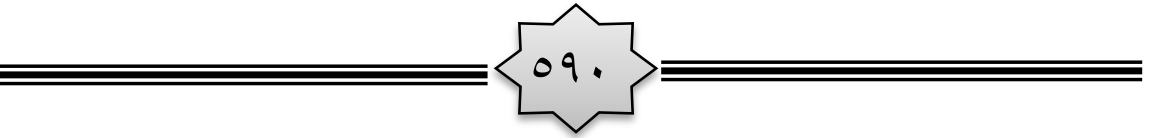


فكثير من هؤلاء زنادقة خبثاء تظهر على أقوالهم وأفعالهح معاندتهم الصريحة للشرع وأحكامه، والمتأمل لتاريخ ظهور هؤلاء يرى أنهم إنما أرادوا هدم الدين من أساسه حيث توجّهت معاولهم إلى الضرب في أصول دين الله وأركانه التي يقوم عليها بدءاً بالتشكيك باله تعالى وأسمائه وصفاته، ومقالاتهم تؤدي في نهايتها إلى نفي وجود الله تعالى، وجعل وجوده وجوداً مطلقاً ذهنياً كما هو حال آلهة اليونان والهندوس وغيرهم، التي وجودها مجرد خرافات وأساطير في أذهانهم المريضة، ليس لها أي رصيد من الواقع. ونفي تقديره وتدبيره لأفعال العباد بل إن متقدمه أنكروا حتى علم الله عز وجل، ونفي وحيه وكلامه بادعاء أنه مخلوق من المخلوقات، وتهوين كل أوامر الله ورسوله بجعل أعمال الطاعة ليست من الإيمان، وزعموا أن فعلها والقيام بها ليس له أي أثر في زيادة إيمانه وعلوّ مرتبته، وفتحوا كل أبواب الفسق والفجور بزعمهم أنه يبقى مؤمناً كامل الإيمان إن كان مصدّقاً وفعل كل الموبقات والكبائر.

ونحو ذلك من المحدثات في العقائد والأحكام. فأرادوا أن يطفئوا نور الله بأفواههم، بعدما رأوا أن هذا النور بدّد ما كانوا عليه من وثنيات في الهند وفارس والروم واليونان، ولم يغب عن ذهنهم توجيه معاول الهحم لذلك 
المجتمع المثالي الوحيد في تاريخ البشرية الذي تحقّق على أرض الواقع بسبب أخذه بوحي الله تعالى وسنته، فاتهموا ذلك الجيل بالسذاجة والغفلة، وعدم معرفتهم بالأدلة العقلية اليقينية، حتى يزيلوا من أذهان الناس أن وحي الله عز وجل هو السبيل الوحيد للحياة الفاضلة السعيدة، وأنه يمكن وجودها في واقع البشر فتكون أموذجاً حياً لمن أراد أن يحتذي بهم وإن لم يبلغ كمالهم، بل فاق مجتمع النبوة في فضائله كثيراً مدينة أفلاطون الفاضلة (اليوتيبيا) التي لم يكن لها وجود في خيالاته وفي أحلام من تبنوا فلسفته بعده. فإذا أضيف إلى هذه كله الطعن في عدالة الصحابة بل وتكفيرهم والحكم بردتهم، وهم حملة السنة والثريعة، فماذا بقي عند الناس من الإسلام بعد هذا كله إن تحقّق مرادهم. والله متم نوره ولو كره المشركون. 


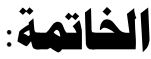

أحمد الله تعالى أن يسّر وأعان على إتمام هذا البحث، والذي تقرّر فيه ما يلي:

أولاً: تواترت النصوص من القرآن الكريم في الأمر بالاتباع والنهي عن

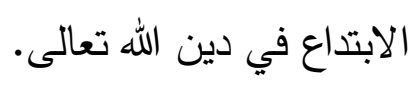

ثانياً: واستفاضت النصوص من السنة النبوية في الأمر بالاتباع

$$
\text { والنهي عن الابتداع في دين الله تعالى. }
$$

ثالثًا: كما تواترت الآثار المروية في تقرير هذا الأصل المهم عن

$$
\text { الصحابة رضي الله عنهم أجمعين. }
$$

رابعًا: وكذلك تواترت الآثار المروية في تقرير هذا الأصل المهح عن

$$
\text { السلف الصالح رحمهم الله تعالى. }
$$

خاهسًا: إن ما ورد عن بعض السلف بتفير الآيات الواردة في

الاعتصام بحبل الله والنهي عن اتباع المتثابه والقول في دين الله بغير

علم ونحو ذلك -حيث حملوه على أهل البدع والأهواء- إنما هو تفسير

لملآية ببعض ما تدل عليه.

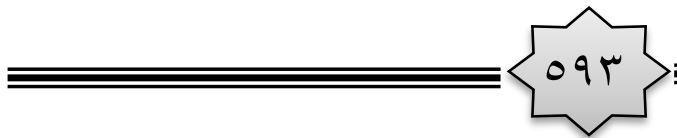


سادساً: إن الروايات الواردة عن السلف في الإغلاظ على أهل البدع والتحذير منهم وهجرهم ونحو ذلك من العقوبات يجب أن تفهم في سياقاتها التاريخية التي قيلت فيها، وحال هؤلاء المبتدعة الذين قيلت في حقهم هذه

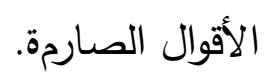
هذا والله أعلم وهو الهادي إلى سبيل الرشاد والتوفيق.

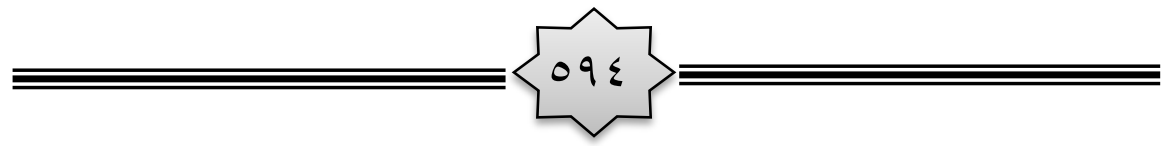




\section{قائهة المادر والمراجع}

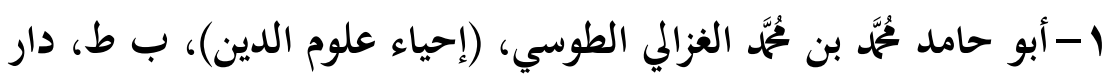

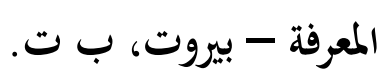

r- أبو عمر يوسف بن عبد الله بن يُمَّمَ بن عبد البر بن عاصم النمري

القرطبي، (الاستيعاب في معرفة الأصحاب)، الطبعة الأولى، دار الجيل -

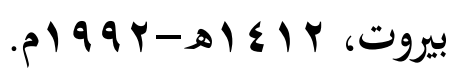

با- أبو بكر بن مُحَّمَ الدمشقي، (كفاية الأخيار في غاية الاختصار)، ب ط،

$$
\text { دار الكتب العلمية - بيروت، ب ت. }
$$

ع-أحمد بن علي بن مُحَّة بن أحمد بن حجر العسقلاني، (الإصابة في تمييز

$$
\text { الصحابة)، الطبعة الأولى، دار العلوم الحديثة - القاهرة، ^ץ 1 اهـ. }
$$

ه- أبو إسحاق إبراهيم بن موسى الشاطبي، (الاعتصام)، الطبعة الأولى، دار

$$
\text { ابن عفان - الحبر، ب إ) إهـ }
$$

צ-أبو الفداء الحافظ بن كثير الدمشقي، (البداية والنهاية)، الطبعة الرابعة،

$$
\text { دار الكتب العلمية - بيروت، م +ـ اهـ. }
$$

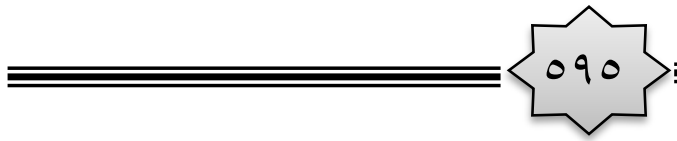


V-V إسماعيل بن مُحَّة بن الفضل التميمي الأصبهالين قوام السنة، (الحجة في

بيان الخجة وشرح عقيدة أهل السنة)، الطبعة الأولى، دار الراية الرياض، الإ اهـ.

^- أبو عبد الرحمن أحمد بن شعيب النسائي، (السنن الكبرى للنسائي)، الطبعة الثانية، دار الكتب العلمية - بيروت، 11 إ اهـ. 9-ابن الجوزي أبو الفرج عبد الرمن بن علي بن مُحَّة، (العلل المتناهية في الأحاديث الواهية)، الطبعة الأولى، دار الكتب العلمية - بيروت، ه

•

والفروق اللغوية)، الطبعة الأولى، مؤسسة الرسالة - بيروت، ب إـ اهـ.

1ا-أبو عبدالله شمس الدين الذهبي، (تذكرة الحفاظ) ب ط، دار الكتب

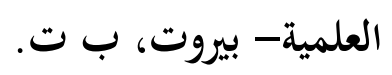

r ا - ابن كثير إسماعيل بن كثير القرشي الدمشقي الإمام الحافظ عماد الدين أبو الفداء، (تفسير القرآن العظيم)، ب ط، دار المعرفة - بيروت، 
با - أحمد بن علي بن مُحَّة بن أحمد بن حجر العسقلاين، (تقريب التهذيب)،

$$
\text { الطبعة الرابعة، دار الرشيد - حلب، Y إع اهـ. }
$$

ع ا - أبو الحسن علي بن مُحَّة بن عراق الكناين، (تنزيه الشريعة المرفوعة عن الأخبار الثنيعة الموضوعة)، الطبعة الثانية، دار الكتب العلمية - بيروت،

$$
\text { . } 1 \leqslant \cdot 1
$$

ه - أحمد بن علي بن مُحَّة بن أحمد بن حجر العسقلالي، (تحذيب التهذيب)،

$$
\text { ب ط، دار الكتاب الإسلامي - القاهرة، ب ت. }
$$

7 ا 1 -أبو نعيم أحمد بن عبد الله الأصفهاين، (حلية الأولياء)، ب ط، دار

$$
\text { الكتب العلمية - بيروت، ب ت. }
$$

IV - أبو عيسى مُحَّة بن عيسى بن سورة الترمذي، (سنن الترمذي)، الطبعة

الثانية، شركة مكتبة ومطبعة مصطفي البابي الحلبي وأولاده - مصر،

$$
.81 \% 9 \Lambda
$$

1 ا - أبو زكريا محيي الدين ييى بن شرف النووي، (شرح صحيح مسلم)، ب

$$
\text { ط، المطبعة المصرية ومكتبتها - مصر، ب ت. }
$$

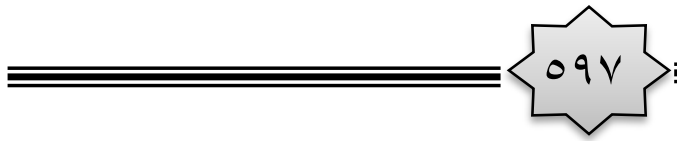


9 ا - أبو الفرج عبد الرحم بن الجوزي، (كتاب الموضوعات)، الطبعة الثانية،

$$
\text { مكتبة ابن تيمية - القاهرة، V • ع اهـ. }
$$

• . - أبو بكر مُحَّة بن الوليد الطرطوشي، (كتاب الحوادث والبدع)، الطبعة

$$
\text { الأولى، دار ابن الجوزي - الدمام، } 7 \text { إع اهـ. }
$$

ا Y-أبو عبد الله شمس الدين الذهبي، (ميزان الاعتدال في نقد الرجال)، ب

$$
\text { ط، دار المعرفة - بيروت، ب ت. }
$$

r r - أبو إسماعيل عبد الله بن مُحََّّ بن علي الأنصاري الهروي، (ذم الكلام وأهله)، الطبعة الأولى، مكتبة العلوم والحكم - المدينة المنورة،

$$
.5199 \wedge-81 \leq 11
$$

rr-أبو الفرج عبد الرحمن بن علي بن مُحَّة الجوزي، (تلبيس إبليس)، الطبعة الأولى، دار الفكر للطباعة والنشر، بيززت، ابع اهـ-1 . . بم.

צ Y - أحمد بن مُحَُّّ بن علي بن حجر الهيتمي، (الفتاوى الحديثية)، ب ط، دار

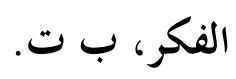

ه Y-أبو عبد الله مُحَّة بن نصر بن الحجاج المَرَوَزي، (السنة)، الطبعة الأولى، مؤسسة الكتب الثقافية - بيروت، 1 • ع ا هـ.

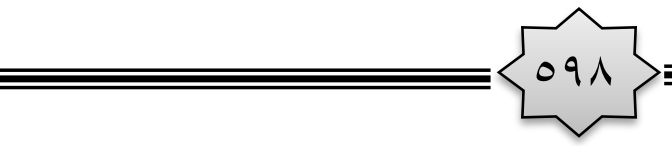


צY - أبو العلا مُحَّمَ عبد الرحمن بن عبد الرحيم المباركفورى، (تحفة الأحوذي

شرح جامع الترمذي)، ب ط، دار الكتب العلمية - بيروت، ب ت.

YV

الأصبهاني، (معرفة الصحابة)، الطبعة الأولى، دار الوطن للنشر -

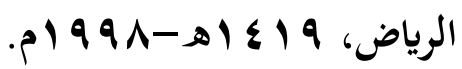

A - أبو العباس شمس الدين أحمد بن مُحََّّ بن إبراهيم بن أبي بكر ابن خلكان

البرمكي، (وفيات الأعيان وأنباء أبناء الزمان)، ب ط، دار صادر -

$$
\text { بيروت، ب ت. }
$$

q Y - الإمام أحمد بن حنبل، (المسند)، الطبعة الثالثة، دار المعارف - مصر،

$$
\text { . } 90 \varepsilon-81 \mathrm{MVH}
$$

• ب- الإمام الحافظ أبو داود سليمان بن الأشعث السجستالي الأسدي، ومعه

كتاب (معالم السنن) للخطابي، (سنن أبي داود)، الطبعة الأولى، دار

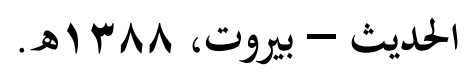

اب-الإمام الدارمي، (رد الإمام الدارمي عثمان بن سعيد علي بشر المريسي

العنيد)، الطبعة الأولى، دار الكتب العلمية - بيروت، I IOV . 
r r-الإمام أبو القاسم هبة الله بن الحسن بن منصور اللالكائي، (شرح

أصول اعتقاد أهل السنة والجماعة)، الطبعة الثانية، دار طيبة - الرياض،

\section{$.8 \leq 11$}

بس-الإمام أبو عبد الله لمُحَّم بن إسماعيل البخاري الجعفي، (صحيح

البخاري)، الطبعة الثالثة، دار ابن كثير - دمثق بيروت، اليمامة -

$$
\text { دمشق بيروت، V · ع اهـ. }
$$

؟ ب-الإمام أبو الحسين مسلم بن الحجّاج القشيري النيسابوري، (صحيح مسلم)، ب ط، المكتبة الإسلامية للطباعة والنشر والثوزيع - استنبول.

هب-الإمام الحافظ أحمد بن علي بن حجر العسقلاين، (فنح الباري بشرح

$$
\text { صحيح البخاري)، ب ط، دار المعرفة للنشر - بيروت، ب ت. }
$$

جس-الإمام أحمد بن حنبل، (مسند الإمام أحمد بن حنبل، وبمامشه منتخب

كنز العمال في سنن الأقوال والأفعال)، ب ط، دار الفكر العربي -

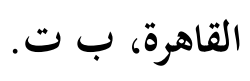

V V-الإمام أحمد بن حنبل، (الزهد)، الطبعة الأولى، دار الكتب العلمية -

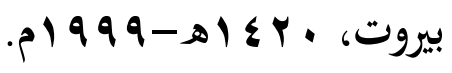

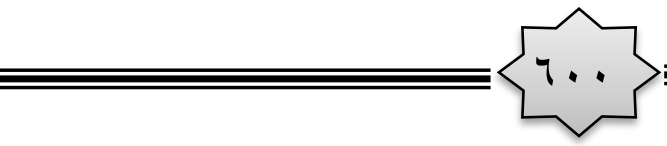


^ץ-بمع: الشيخ عبد الرمن بن قاسم، (جمموع الفتاوى شيخ الإسلام أحمد

بن تيمية)، ب ط، مجمع الملك فهد لطباعة المصحف الثريف، المدينة

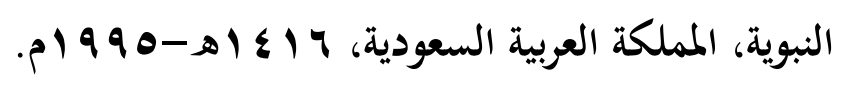

9 ج-حافظ بن أحمد حكمي، (معارج القبول بشرح سلم الوصول)، الطبعة

$$
\text { الثالثة، دار ابن القيم - الدمام، ؟ إ أهـ. }
$$

• ع-الحافظ أبو بكر بن أبي عاصم الشيباني، (السنة)، الطبعة الأولى،

$$
\text { المكتب الإسلامي - بيروت، . - ـ اله. }
$$

اــ-الحاكم النيسابوري الإمام الحافظ أبو عبد الله مُحَّمَ بن عبد الحكيم،

(المستدرك على الصحيحين)، الطبعة الأولى، دار الكتب العلمية -

$$
\text { بيروت، | (1) أه. }
$$

ب أ- الحافظ بمال الدين أبو الحجاج يوسف المزي، (تذذيب الكمال في أسماء

$$
\text { الرجال)، الطبعة السادسة، مؤسسة الرسالة - بيروت، } 10
$$

بـ - الحافظ أبو عبد الله مُمََّّ بن يزيد القزويني، (سنن ابن ماجه)، ب ط، دار

$$
\text { إحياء الكتب العربية - القاهرة، دار الريان للتراث، ب ت. }
$$

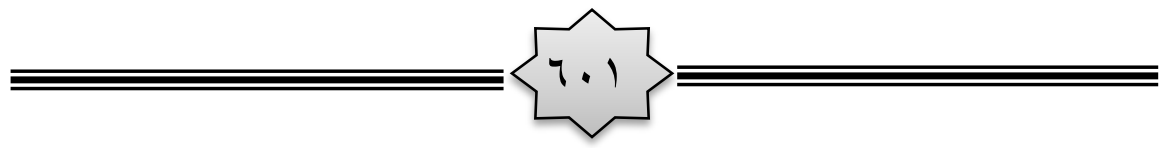


ع - الحافظ أبو عبد الرحمن بن شعيب النسائي، ومعه (زهر الربى على

الججتى) للحافظ الجلال السيوطي، (سنن النسائي، الجمتى)، شركة مكتبة ومطبعة مصطفي البابي الحلبي وأولاده - مصر، سمب اهـ.

هـ-الخطيب البغدادي الحافظ أبو بكر أحمد بن علي، (تاريخ بغداد)،

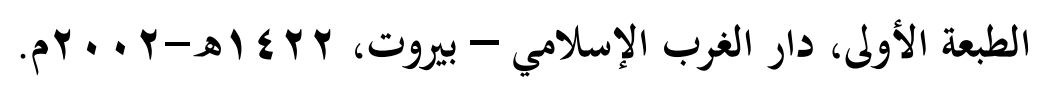

ج ع - سليمان بن حمد العودة، (عبد الله بن سبأ وأثره في إحداث الفتنة في

$$
\text { صدر الإسلام)، الطبعة الثانية، دار طيبة - الرياض، ب إع اهـ. }
$$

\& V

$$
\text { لمخالفة أصحاب الجحيم)، الطبعة الأولى ع · ع اهـ. }
$$

^ع - شمس الدين أبو عبد الله مُحَّمَ بن أحمد بن عثمان بن قَيْماز الذهبي، (سير

أعلام النبلاء)، الطبعة التاسعة، مؤسسة الرسالة - بيروت، با إ اهـ.

9 - شيخ الإسلام أحمد بن عبد الحليم ابن تيمية، (نقض المنطق)، ب ط،

$$
\text { مكتبة السنة الحمدية - القاهرة، • م اهـ. }
$$

• ه-شيخ الإسلام أحمد بن عبد الحليم بن تيمية، (الاستقامة)، الطبعة

$$
\text { الأولى، جامعة الإمام مُحََّّ بن سعود - الرياض، ب • ع اهـ. }
$$

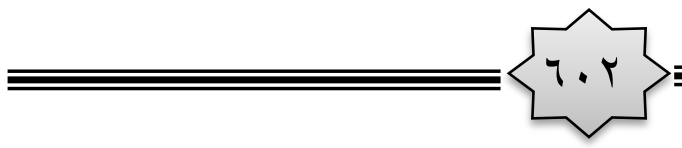


اهـ-عبيد الله بن مُحََّّ بن بطة بن العكبري الحنبلي، (الإبانة عن شريعة الفرقة

الناجية ومجانبة الفرقة المذمومة)، الطبعة الأولى، دار الراية - الرياض،

ro - r علي بن مُحَّة بن سلطان الملاعي القاري، (الأسرار المرفوعة في الأخبار الموضوعة)، الطبعة الثانية، المكتب الإسلامي - بيروت، 7 • ع اهـ.

به-عبد الله بن أحمد بن حنبل الشيبالي، (السنة)، الطبعة الثانية، رمادي

$$
\text { للنشر - الدمام، المؤتمن للتوزيع - الرياض، ع ا ع اهـ. }
$$

ع ه-عبيد الله بن مُحَّة بن بطة بن العكبري الحنبلي، (الشرح والإبانة على

أصول السنة والديانة، ومجانبة المخالفين ومباينة أهل الأهواء المارقين)، ب

$$
\text { ط، مكتبة الفيصلية - مكة المكرمة، ع • ع اهـ. }
$$

هـ-عبد الله بن عبد الرحمن بن الفضل أبو مُحَّمَ الدارمي، (سنن الدارمي)،

$$
\text { الطبعة الأولى، دار القلم - دمشق، Y I ـ اهـ. }
$$

צه-علي بن مُحَّة بن علي الزين الشريف الجرجاني، (التعريفات)، الطبعة

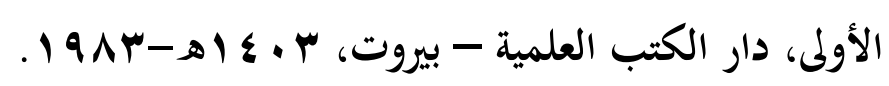

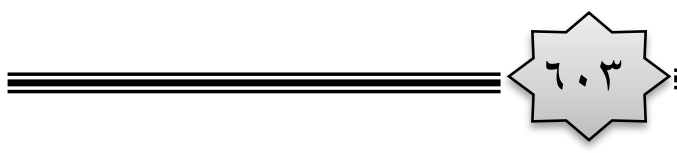


-OV الأحاديث الموضوعة)، الطبعة الأولى، دار الكتب العلمية - بيروت،

$$
.61997-81 \leq 12
$$

^ه-عبد الرحمن بن مُحَّمَ بن إدريس بن المنذر التميمي ابن أبي حاتم الرازي، (آداب الثافعي وناقبه)، الطبعة الأولى، دار الكتب العلمية - بيروت،

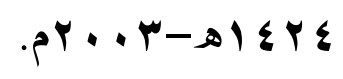

9ه-عبد الرمن بن أبي بكر، جلال الدين السيوطي، (الأمر بالاتباع والنهي

$$
\text { عن الابتداع)، ب ط، مطابع الرشيد - الرياض، } 9 \text { ـ ـ أه. }
$$

• ฯ- مُحَّمَ بن أحمد الذهبي، (تاريخ الإسلام ووفيات المشاهير والأعلام)،

$$
\text { الطبعة الثانية، دار الكتاب العربي بيروت، با إ اهـ. }
$$

الج- مُحَّمَ بن جرير الطبري، (تَذيب الآثار وتفصيل معاني الثابت عن رسول

الله

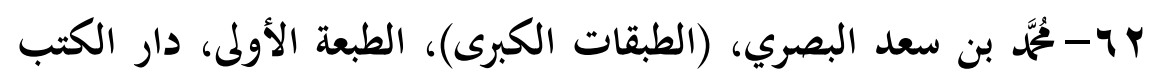
العلمية - بيروت، • إ اهـ. 
بَ- مُحَّة بن أبي يعلى القاضي أبو الحسين، (طبقات الحنابلة)، ب ط، دار

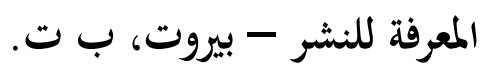

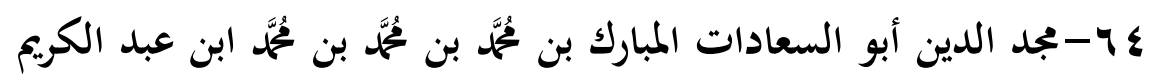

الثيباني الجزري ابن الأثير ، (النهاية في غريب الحديث والأثر)، ب ط،

$$
\text { دار الفكر الإسلامي الحديث - القاهرة، . . . . P. }
$$

ه - مُحَّة ناصر الدين الألبالي، (إرواء الغليل في تخريج أحاديث منار السبيل)،

$$
\text { الطبعة الثانية، المكتب الإسلامي - بيروت، هـ ـ ع اهـ. }
$$

צ

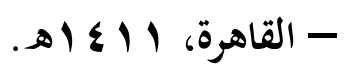

VV Vحيي الدين أبو مُحَّة الحسين بن مسعود البغوي، (تفسير البغوي، معالم

$$
\text { التنزيل)، الطبعة الثانية، دار طيبة للنشر والتوزيع - الرياض، } 9 \text { ، ع اهـ. }
$$

^צ- مُحَّة ناصر الدين الألباني، (سلسلة الأحاديث الصحيحة)، الطبعة

$$
\text { الرابعة، المكتب الإسلامي - بيروت، ه م ع اهـ. }
$$

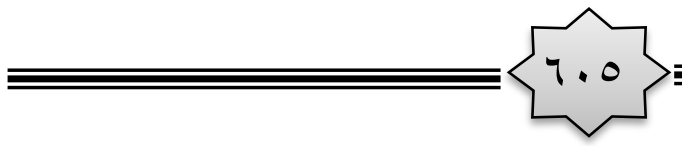


9 7- مُحَّة ناصر الدين الألبالي، (سلسلة الأحاديث الضعيفة والموضوعة وأثرها

السيء في الأمة)، الطبعة الرابعة، المكتب الإسلامي - بيروت،

$$
\text { . D . } 0
$$

•

$$
\text { الثانية، المكتب الإسلامي - بيروت، ب • ع اهـ. }
$$

ا

$$
\text { الثانية، المكتب الإسلامي - بيروت، } 7 \text { • ع اهـ. }
$$

-VY

$$
\text { مكتب التربية العربي لدول الخليج - الرياض، } 9 \text { • ع اهـ. }
$$

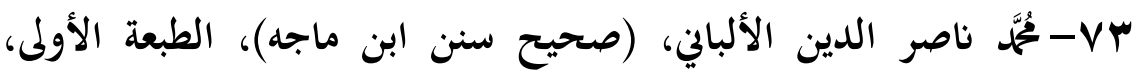

$$
\text { مكتب التربية العربي لدول الخليج - الرياض، م • ع اهـ. }
$$

ع -Vمُحَّ ناصر الدين الألباني، (صحيح سنن الترمذي)، الطبعة الأولى،

$$
\text { مكتب التربية العربي لدول الخليج - الرياض، م • ع اهـ. }
$$

ه-Vمُحَّم ناصر الدين الألبالي، (صحيح سنن النسائي)، الطبعة الأولى،

$$
\text { مكتب التربية العربي لدول الخليج - الرياض، } 9 \text { • ع اهـ. }
$$

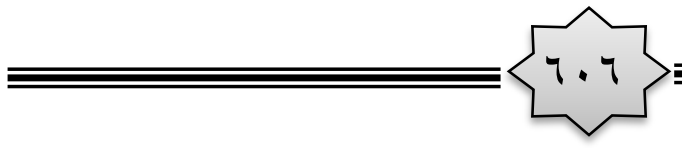


צ-VY

$$
\text { الأولى، المكتب الإسلامي - بيروت، 1 أهـ. }
$$

-VV

$$
\text { المكتب الإسلامي - بيروت - دمشق - عمان، ب إع اهـ. }
$$

-VA

$$
\text { المكتب الإسلامي - بيروت - دمشق، } 1 \text { • ـ اهـ. }
$$

-V9

$$
\text { المكتب الإسلامي - بيروت - دمثق - عمان، } 11 \text { | اهـ. }
$$

•

$$
\text { المكتب الإسلامي - بيروت - دمشق - عمان، } 1 \text { إع اهـ. }
$$

ا \- مُحَّة بن عبد الله الخطيب التبريزي، (مشكاة المصابيح)، الطبعة الثالثة،

$$
\text { المكتب الإسلامي - بيروت - دمشق، ه ـ ـ اهـ. }
$$

Y Y Y نور الدين علي بن بن أبي بكر الهيثمي، (بجمع الزوائد ومنبع الفوائد)،

$$
\text { ب ط، دار الفكر - القاهرة، ب ت. }
$$




\section{المتويات}

$0 \leqslant Y$

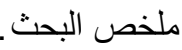

$0 \leqslant 0$ المقدمة:

oOr

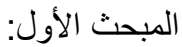

07 .

المبحث الثاني

Tr

المبحث الثالث

ov.

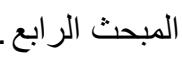

ONT

المبحث الخامس

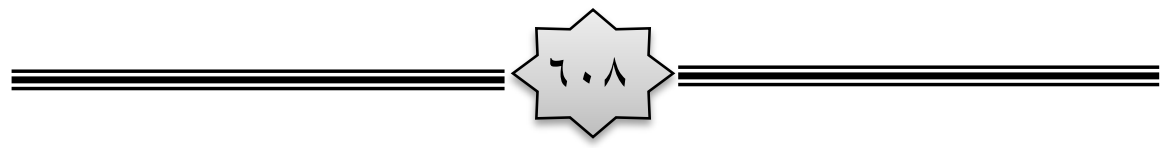




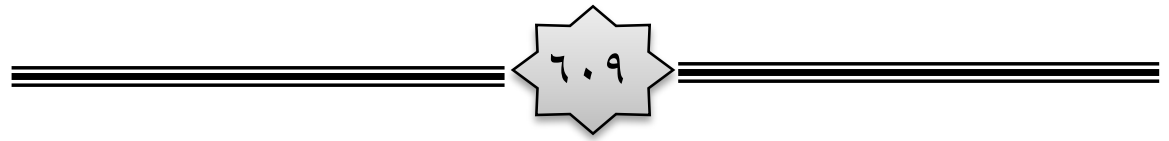


فهرس موضوعات المجلد الأول

قسم الأديان والمذاهب

\begin{tabular}{|c|c|c|c|}
\hline |لصفمة & مش & مرث & $\theta$ \\
\hline $1 \times q-1$. & 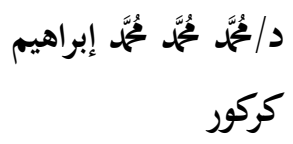 & مفهوم الاستشراق وصلته بأجنحة & 1 \\
\hline$r q 1-1 r v$ & 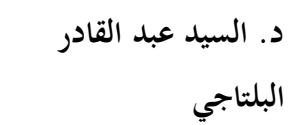 & 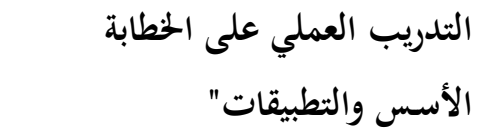 & r \\
\hline r.r-r r & إبراهيم أحمد الامام & تلتوظيف أصحاب الأفكار المتطرفة & $r$ \\
\hline$r q r-r \cdot \varepsilon$ & أحمد علاح سعد الدين & إقعنا المعاصر & $\varepsilon$ \\
\hline$\varepsilon q .-r q r$ & دالأشوليزة علي & الثأصيل العقدي في غرس عقائد & 0 \\
\hline$\Delta r \wedge-\varepsilon q 1$ & د. إيناس حُمُحَّ الغرايبه & تخصيص عام & 7 \\
\hline $9.1-0 r q$ & أسرار عبد المنعم عبد الففور & موقف السلف في أئمة البدعة ودعاة & v \\
\hline
\end{tabular}

